Article

\title{
Chemical-Petrographic Types and Shock Metamorphism of 184 Grove Mountains Equilibrated Ordinary Chondrites
}

\author{
Deqiu Dai ${ }^{1, *}$, Shuang Liu ${ }^{1,2}$ and Xuemei Liu ${ }^{1,2}$ \\ 1 Institute of Geology, Hunan University of Science and Technology, Xiangtan 411201, China; \\ 1s93272035@163.com (S.L.); 17711624399@163.com (X.L.) \\ 2 Hunan Provincial Key Laboratory of Shale Gas Resource Utilization, Xiangtan 411201, China \\ * Correspondence: 1020099@hnust.edu.cn; Tel.: +86-731-5829-0045
}

Received: 19 April 2018; Accepted: 1 June 2018; Published: 4 June 2018

\begin{abstract}
We reported the petrography and mineral chemistry of 184 equilibrated ordinary chondrites collected from Grove Mountains, Antarctica. The chemical-petrographic types and shock metamorphism degrees of these chondrites were assigned. They were classified into $46 \mathrm{H}$ groups ( $22 \mathrm{H} 4,20 \mathrm{H} 5$, and four H6), 133 L groups (eight L4, 75 L5, and 50 L6), and five LL groups (four LL4 and one LL5). Some of these chondrites could be paired; however, both $\mathrm{H}$ and $\mathrm{L}$ group meteorites were affected. Further studies such as terrestrial ages and thermal luminescence are required in order to confirm the pairings. The relative abundances of $\mathrm{H}, \mathrm{L}$, and LL are different in Grove Mountain meteorites, when compared to those in Transcontinental Ridge meteorites. Based on the shock effects, the shock metamorphism degrees of these chondrites were assigned. Compared to previous studies, the heavily shocked samples of S4 and S5 have a higher fraction (59 out of 184) in Grove Mountain ordinary chondrites. The L group (54 out of 59) is the dominant chemical group in the heavily shocked chondrites, except for five meteorites which belong to the $\mathrm{H}$ group. The shock metamorphism degrees of the $\mathrm{H}$ and $\mathrm{L}$ groups are distinct, which may indicate different surface properties in their parent bodies. In addition, the petrologic types and shock degrees are probably closely related, with the most heavily shocked chondrites observed in types 5 and 6 .
\end{abstract}

Keywords: chemical-petrographic types; shock metamorphism; chondrites; Grove Mountains; Antarctica

\section{Introduction}

Since the first discovery of nine meteorites of different chemical groups in the Yamato area, Antarctica by a Japanese team in 1969, Antarctica has become the most meteorite-rich region in the world. Many rare types of meteorites have been found in Antarctica, e.g., Martian meteorites, Lunar meteorites, and carbonaceous chondrites. The Grove Mountains consist of 64 nunataks, which are located in eastern Antarctica [1]. During the 15th Chinese Antarctic exploration between 1998 and 1999, a Chinese team conducted their first field survey of the Grove Mountains. More than 10,000 meteorites were collected by the Chinese Antarctic Research Expedition (CHINARE) in this area (Figure 1).

With a large number of Antarctica meteorites found, some comparative studies could be conducted, e.g., the type and mass distribution patterns and shock metamorphism in different chemical and petrographic chondrite types. Previously, some studies showed that there is no close connection between the distribution patterns of the types and mass, and the sites where the meteorites are collected [2-4]. On the other hand, some large meteorite showers have been evidenced in Antarctica. Locally, these showers do result in establishing a connection between meteorite types, 
mass, and sites [5]. Shock metamorphism from hypervelocity collisions is the most common feature of meteorite parent bodies. Deformation, melting, and the decomposition of mineral components are recorded under shock effects [6,7]. Moreover, natural high-pressure polymorphs of rock-forming minerals were also discovered in heavily shocked meteorites [6-10]. Since the high pressures and temperature conditions during shock events are comparable to those of the Earth's transition zone or of the lower mantle, the study of shock effects in meteorites is of great importance for deciphering the collisional and geological history of their asteroidal parent bodies [11,12]. Based on the shock effects in silicate minerals and shock-induced localized melting in ordinary chondrites, seven degrees of shock metamorphism (S1-S6 and shock melted) were classified by Stőffler et al.; the Pressure-Temperature (P-T) conditions of every shock degree were also given in their study [13].

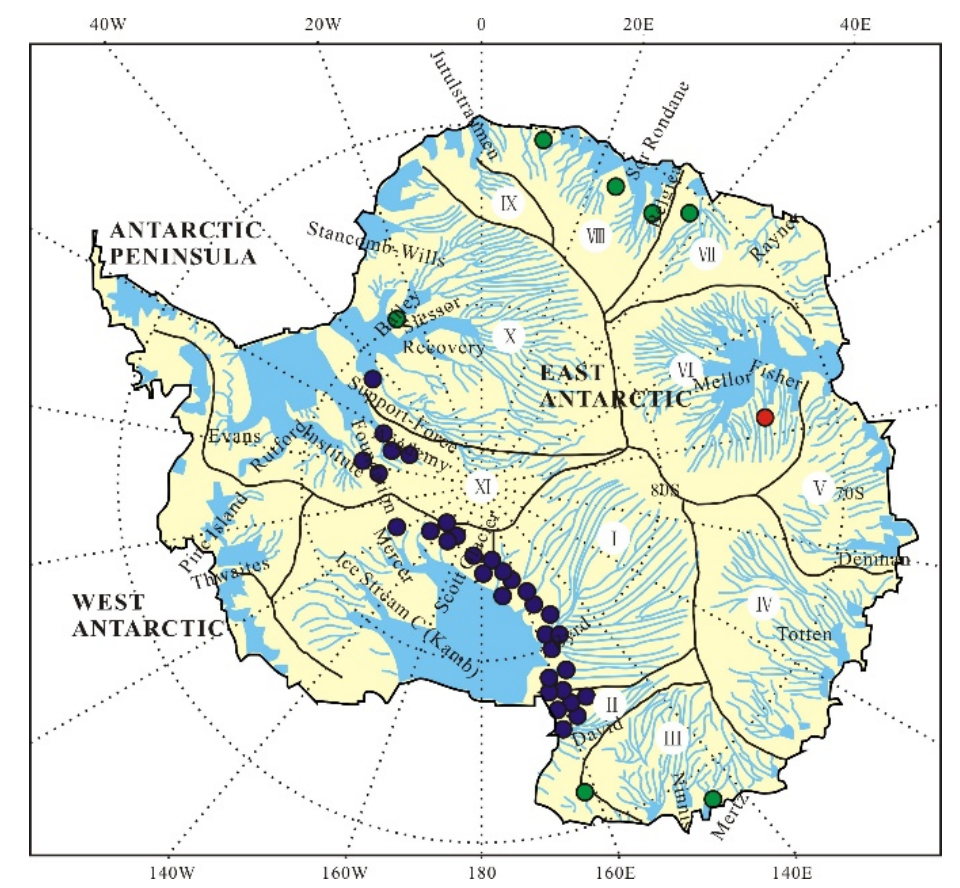

Figure 1. Map of meteorite concentration sites in Antarctica (based on the literature [14]). The red dots, blue dots, and green dots represent the meteorite enrichment areas found by China, the United States, and Japan and other countries, respectively.

In order to compare the type distribution patterns and shock metamorphism degrees with different chemical-petrographic types in chondrites, 184 equilibrated ordinary chondrites were randomly selected for classification. In this paper, the petrography and mineral chemistry of these meteorites are reported, and their chemical-petrographic types and shock metamorphism degrees are assigned.

\section{Samples and Experiments}

Samples of these meteorites were embedded in epoxy, and then cut into $<1 \mathrm{~mm}$ thin slices with a low-speed diamond saw. They were prepared to standard polished thin sections without water. Textural observations of these chondrites were studied using an optical microscope and a back-scattered electron (BSE) image model of a JEOL 8100 electronic probe microanalyzer (EPMA) (Tokyo, Japan) at the Guangzhou Institute of Geochemistry, Chinese Academy of Sciences. Quantitative analyses for silicates were carried out using the same EPMA with a $15 \mathrm{keV}$ accelerating voltage and a $20 \mathrm{nA}$ beam current. Natural and synthetic minerals were used as standards. An X-ray peak deconvolution program was applied to correct for the $\mathrm{K}_{\alpha}$ lines of $\mathrm{V}$ and $\mathrm{Mn}$ by the $\mathrm{K}_{\beta}$ lines of Ti and Cr. Analytical results of the silicates ware corrected by the ZAF method. Modal contents of opaque mineral (metallic Fe-Ni and troilite) were calculated from areas of the phase in BSE images of the polished thin sections. 
Chemical-petrographic types of these chondrites are mainly based on References [15-17], and their shock metamorphism results are based on Reference [13].

\section{Chemical-Petrographic Types}

The basic characteristics of these Grove Mountains chondrites are summarized in Table A1, including chemical-petrographic types, found location, mass, opaque mineral (vol \%), mineral chemistry, and shock metamorphism. They are all equilibrated, including 46 meteorites classified as $\mathrm{H}$ chondrites ( $22 \mathrm{H} 4,20 \mathrm{H} 5$, and four H6), $133 \mathrm{~L}$ chondrites (eight L4, 75 L5, and $50 \mathrm{~L} 6$ ), and five LL chondrites (four LL4 and one LL5).

All 184 meteorites have homogenized mineral chemistry and their matrices are recrystallized (Figure 2). This indicates that they experienced significant thermal metamorphism in their parent bodies. Type 5 and 6 chondrites have blurred outlines of chondrules (Figure 2c,d), but chondrules are clearly outlined in type 4 (Figure 2a,b). The PMD (percent mean deviation) value of the Fa (Fayalite) content of olivine in all chondrites is most $<5 \%$. Low-Ca pyroxene is also homogeneous in most of these chondrites, with a PMD of Fs (ferrosilite) content $<5 \%$. The Fa content of olivine and Fs content of low-Ca pyroxene of these meteorites are plotted in Figure 3.
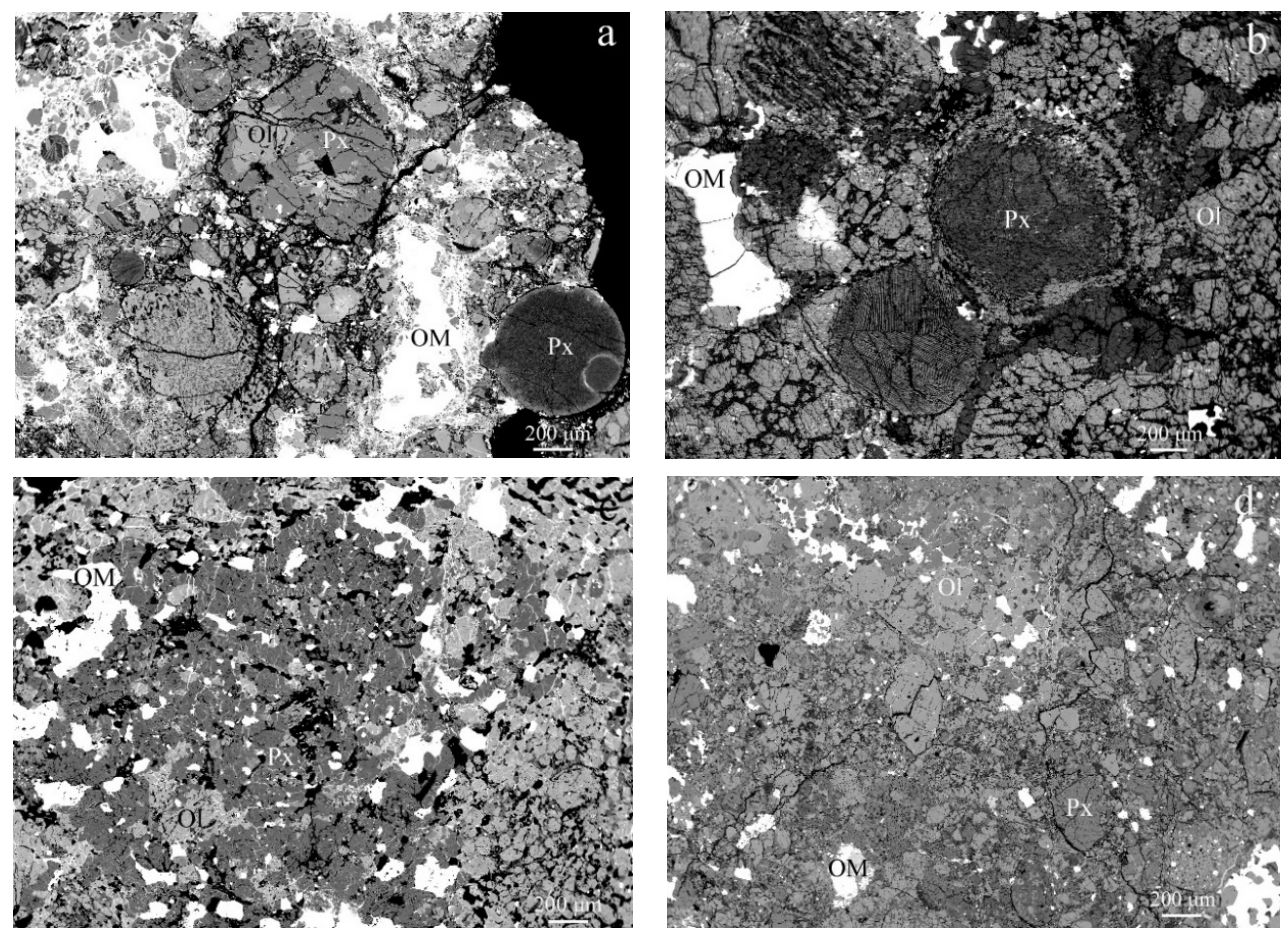

Figure 2. Back-scattered electron (BSE) images of representative equilibrated ordinary chondrites. (a) GRV 020008 (H4); (b) GRV 020038 (L4); (c) GRV 022178 (L6); (d) GRV 020041 (LL4). Ol—olivine, Px-pyroxene, OM-opaque mineral.

\subsection{Group $H$}

There are 46 meteorites in this group (Table A1). The Fa values of olivine for all chondrites range from 17.0 to $21.0 \mathrm{~mol} \%$, and the Fs values of low-Ca pyroxene range from 15.4 to $18.5 \mathrm{~mol} \%$. Both the Fa and Fs tally with the ranges of the H group (Figure 3). These 46 meteorites experienced significant thermal metamorphism. Twenty-two meteorites (Table A1) have a homogenized mineral chemistry and clear outlines of chondrules. Additionally, their fine-grained matrices are partly recrystallized (Figure 2a), with the sizes of the recrystallized matrices being 5-15 $\mu \mathrm{m}$. Brown-colored glass was found in a few chondrules. Accordingly, these meteorites belong to H4. The outlines of the chondrules in 20 chondrites (Table A1) can been recognized. Additionally, their matrices are well 
recrystallized, with the sizes of these grains being 10-40 $\mu \mathrm{m}$. Secondary feldspar within the matrix and chondrules is popular, with sizes ranging from $10-50 \mu \mathrm{m}$. These 20 chondrites were assigned to H5. They were identified as GRV 020072, 020093, 020098, and 021522, having similar petrographic characteristics. Additionally, their matrices are intensely recrystallized, with the sizes of these grains being $50-150 \mu \mathrm{m}$. The chondrules in these meteorites are hard to locate, with only a few fragments remaining. These chondrites belong to type H6.

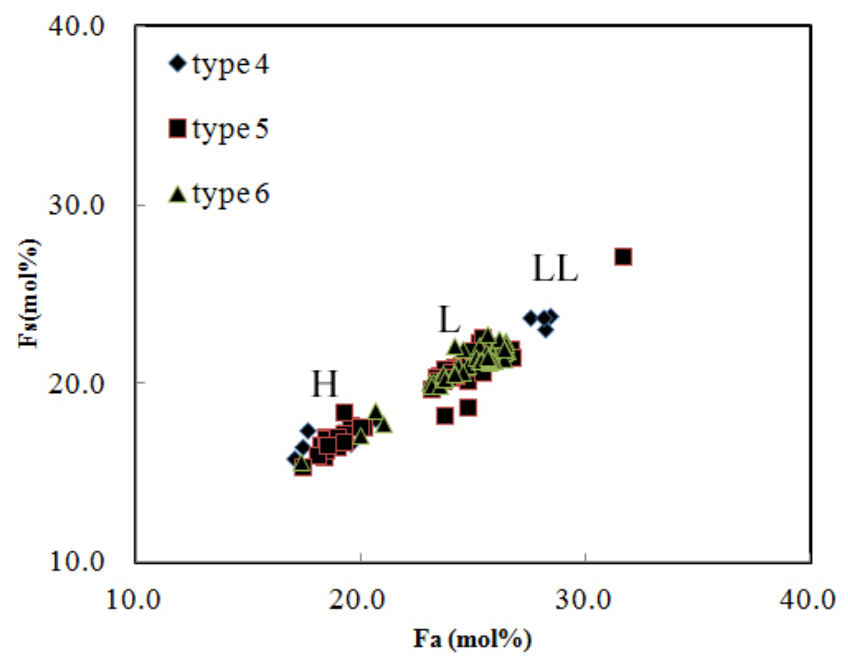

Figure 3. Fa of olivine and Fs of low-Ca pyroxene of 184 chondrites.

\subsection{Group $L$}

One hundred and thirty-three meteorites belong to the L group, and they are equilibrated (Table A1). The Fa values of olivine in all the chondrites range from 23.0 to $26.7 \mathrm{~mol} \%$, and the Fs values of low-Ca pyroxene range from 18.2 to $22.8 \mathrm{~mol} \%$. Both Fa and Fs values are within the ranges of the group L (Figure 3). These chondrites (GRV 020038, 020049, 021643, 021654, 021668, 021726,021800 , and 022221) have a homogenized mineral chemistry and clear outlines of chondrules. Additionally, their fine-grained matrices are only partly recrystallized (Figure 2b), with the sizes of the recrystallized matrices being $5-10 \mu \mathrm{m}$. The primary glass was found in a few chondrules. This indicates that these meteorites experienced the lowest degree of thermal metamorphism. However, all eight chondrites can be assigned to type L4. In 75 meteorites (Table A1), many chondrules are fractured and occur as fragments, but they can be recognized. The matrices of these chondrites are well recrystallized $(20-40 \mu \mathrm{m})$, with plagioclase being commonly observed. These meteorites belong to L5. The other 50 meteorites (Table A1) were assigned to type L6. Additionally, their matrices were intensely recrystallized, with the sizes of these grains being 50-200 $\mu \mathrm{m}$. Only a few fragments of chondrules can be found (Figure 2c).

\subsection{Group $L L$}

Only five chondrites were assigned to this group (Table A1), i.e., GRV 020019, 020021, 020028, 020037, and 020041. The modal abundances of the opaque mineral (0.6-4.1 vol \%), along with the compositions of olivine (mean Fa: 27.5-31.6 mol \%) and low-Ca pyroxene (mean Fs: 23.1-27.2 mol \%), indicate that these meteorites belong to the LL group. GRV 020019 experienced a much stronger thermal metamorphism than the other four meteorites. In GRV 020019, only a few chondrules could be readily recognized. In contrast, in GRV 020021, 020028, 020037, and 020041, the chondrules are clearly outlined (Figure $2 \mathrm{~d}$ ), with their matrices being only partly recrystallized (Figure 2d), and with the sizes of these matrices being 5-20 $\mu \mathrm{m}$. Brown-colored glass was found in a few chondrules. Therefore, GRV 020021,020028, 020037, and 020041 were classified as LL4, and GRV 020019 as LL5. 


\section{Discussion}

\subsection{Type and Mass Distribution Patterns}

Based on the statistics of the classified 184 equilibrated ordinary chondrites, the relative abundances of $\mathrm{H}, \mathrm{L}$, and LL groups were $25 \%, 72.3 \%$, and $2.7 \%$, respectively. The relative abundance of $\mathrm{L}$ chondrites was as high as by a factor of $\sim 2.9$ of the H group, while the LL chondrites were rather few in number. Figure 4 shows the type distribution patterns of the Grove Mountain meteorites in this paper when compared with those of Transcontinental Ridge meteorites [16]. The abundance ratio of H:L:LL was 25:72.3:2.7 for meteorites from the Grove Mountains, which is different from that of the Transcontinental Ridges (42:48:10) [16]. It is clear that the Grove Mountain chondrites have a higher abundance of the L chemical group and less H and LL groups when compared with the Transcontinental Ridge chondrites.

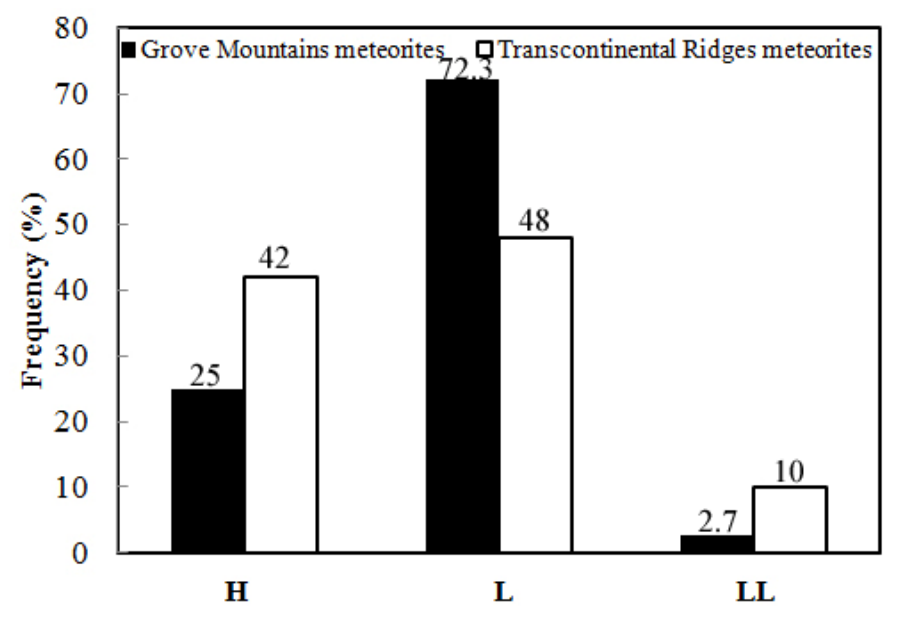

Figure 4. Comparison of the distribution patterns of the chondrite chemical groups between the Transcontinental regions and the Grove Mountains.

The Grove Mountain meteorites have smaller sizes (average mass of $67.9 \mathrm{~g}$ ) when compared with the Transcontinental Ridge meteorites (average mass of $261.3 \mathrm{~g}$ ) [16]. The abundance of Grove Mountain meteorites decreases exponentially with the increase of mass. Tiny meteorites (mass $<25 \mathrm{~g}$ ) are more than 50\%. Many Grove Mountain meteorites are small fragments that were found very close to one another. Therefore, they are probably broken pieces from some larger meteorites. On the other hand, the field team in the Grove Mountains searched for meteorites by foot, finding meteorites as small as $0.1 \mathrm{~g}$, while blue ices along the Transcontinental Ridges were swept with a skidoo or snowmobile.

Because of the transfer and concentration of meteorites by glacier and wind, the meteorites collected from the same region in Antarctica face two possibilities: (1) each piece belongs to individual fall events, or (2) some of them may be pieces of the same meteorite fall (meteorite shower, or paired meteorites) $[5,16]$. Different search methods were employed between the Grove Mountains (by foot) and the Transcontinental Ridges (skidoo), so smaller meteorites could be found in the Grove Mountains. As discussed above, the abundance ratio of L:H was 2.9; thus, it is obvious that the Grove Mountains have a greater L group presence and a lower $H$ group presence when compared with the Transcontinental Ridges. The abundance ratio of L:H was 5.6 (Table A1) if we limit ourselves to Grove Mountains meteorites with a mass $>10 \mathrm{~g}$. Therefore, the higher H:L ratio in the Grove Mountains is not related to the mass. Both $\mathrm{H}$ and L group meteorites were affected, whether they were from a meteor shower or pieces broken from some larger meteorites. In this paper, we reported the petrography and mineral chemistry of 184 equilibrated ordinary chondrites. However, further studies such as terrestrial ages and thermal luminescence are required in order to confirm the pairing. 


\subsection{Shock Metamorphism}

A petrographic classification of shock metamorphism degrees of ordinary chondrites was put forward by Stőffler et al. [13] and has since been widely used [16-19]. According to their classification, seven shock metamorphism degrees (S1-S6 and shock melted) were defined, based on the shock effects in the main silicate components, as recognized by thin section microscopy. The characteristic shock effects of each shock degree are (Table 1): S1 (unshocked)—sharp optical extinction of olivine; S2 (very weakly shocked)—undulatory extinction of olivine; S3 (weakly shocked)-planar fractures in olivine; S4 (moderately shocked)—mosaicism in olivine; S5 (strongly shocked)—isotropization of plagioclase (maskelynite) and planar deformation features in olivine; and S6 (very strongly shocked-recrystallization of olivine, sometimes combined with phase transformations (ringwoodite and/or phases produced by dissociation reactions). S6 effects are always restricted to regions adjacent to melted portions of a sample which is otherwise only strongly shocked [13]. With the development of high-pressure experiments and study in shock metamorphism in meteorites, modifications and corrections were made on the Pressure-Temperature-time (P-T-t) conditions and formation history of high-pressure minerals in meteorites [11,20-22]. Accordingly, modifications and revisions are needed for the current classification and pressure calibration system of shock degrees in ordinary chondrites (Table 1). In this study, we classified the shock degrees of 184 Grove Mountain ordinary chondrites (see Tables 1 and A1). The shock metamorphism degrees of the 184 chondrites are S1 (10 meteorites), S2 (61 meteorites), S3 (54 meteorites), S4 (54 meteorites), and S5 (five meteorites) (Figure 5), respectively.

Table 1. Shock metamorphism degrees of Grove Mountains chondrites (based on the literature [13]).

\begin{tabular}{|c|c|c|c|c|c|}
\hline \multirow{2}{*}{ Shock Degree } & \multicolumn{3}{|c|}{ Silicates } & \multirow{2}{*}{ Local Effects } & \multirow{2}{*}{ Results } \\
\hline & Olivine & Pyroxene & Plagioclase & & \\
\hline S1 & \multicolumn{3}{|c|}{$\begin{array}{l}\text { sharp optical extinction and irregular } \\
\text { fractures }\end{array}$} & none & 10 \\
\hline S2 & \multicolumn{3}{|c|}{ undulose extinction and irregular fractures } & none & 61 \\
\hline S3 & \multicolumn{3}{|c|}{$\begin{array}{l}\text { planar fractures undulose extinction and } \\
\text { irregular fractures (a few ringwoodite) }\end{array}$} & $\begin{array}{l}\text { opaque shock veins, } \\
\text { incipient formation of } \\
\text { melt pockets }\end{array}$ & 54 \\
\hline S4 & \multicolumn{3}{|c|}{$\begin{array}{l}\text { planar fractures weak mosaicism } \\
\text { ringwoodite maskelynite }\end{array}$} & $\begin{array}{l}\text { opaque shock veins } \\
\text { and melt pockets } \\
\text { interconnecting }\end{array}$ & 54 \\
\hline S5 & \multicolumn{3}{|c|}{$\begin{array}{l}\text { planar fractures strong mosaicism } \\
\text { ringwoodite maskelynite (a few } \\
\left.(\mathrm{Mg}, \mathrm{Fe}) \mathrm{SiO}_{3} \text {-glass }\right)\end{array}$} & $\begin{array}{l}\text { pervasive melt pockets } \\
\text { and shock veins }\end{array}$ & 5 \\
\hline S6 & \multicolumn{3}{|c|}{$\begin{array}{l}\text { in or near the shock induced-veins, } \\
\text { solid state recrystallization of silicates }\end{array}$} & $\begin{array}{l}\text { pervasive melt pockets } \\
\text { and shock veins }\end{array}$ & 0 \\
\hline
\end{tabular}

Figure 6 shows the statistic results of the shock metamorphism degrees within different chemical groups and petrologic types of these Grove Mountain chondrites. Due to its low abundance, the LL group was not considered. The $\mathrm{H}$ and $\mathrm{L}$ groups displayed distinct abundance patterns. Specifically, $41 \%$ of $\mathrm{L}$ chondrites were heavily shocked (S4-5) with an occurrence of shock-induced melt veins, while the shock metamorphism is not so extensively developed in $\mathrm{H}$ group chondrites. Most $\mathrm{H}$ chondrites were weakly shocked, with only four meteorites classified as S4 (Figure 6a).

Stôffler et al. studied the shock metamorphism in $35 \mathrm{H}$ group, 27 L group, and 14 LL group chondrites. Their results showed that the differences in the frequency distribution of shock degrees in $\mathrm{H}, \mathrm{L}$, and LL groups are minor; besides, the shock effects and the sequence of progressively increasing degrees of shock metamorphism are very similar [13]. However, the investigation of the Meteoritical Bulletin Database suggests that the frequency distributions of shock degrees between $\mathrm{L}$ and $\mathrm{H}$ groups are different [11]. There are $23 \mathrm{~L}$ group out of all the chondrites that are shocked to S4-S6, whereas the number of $\mathrm{H}$ groups is nine. It is evident that the $\mathrm{L}$ group chondrites have experienced a stronger 
shock metamorphism than those of the H group [23], which is consistent with the results in this study (Figure 6a).
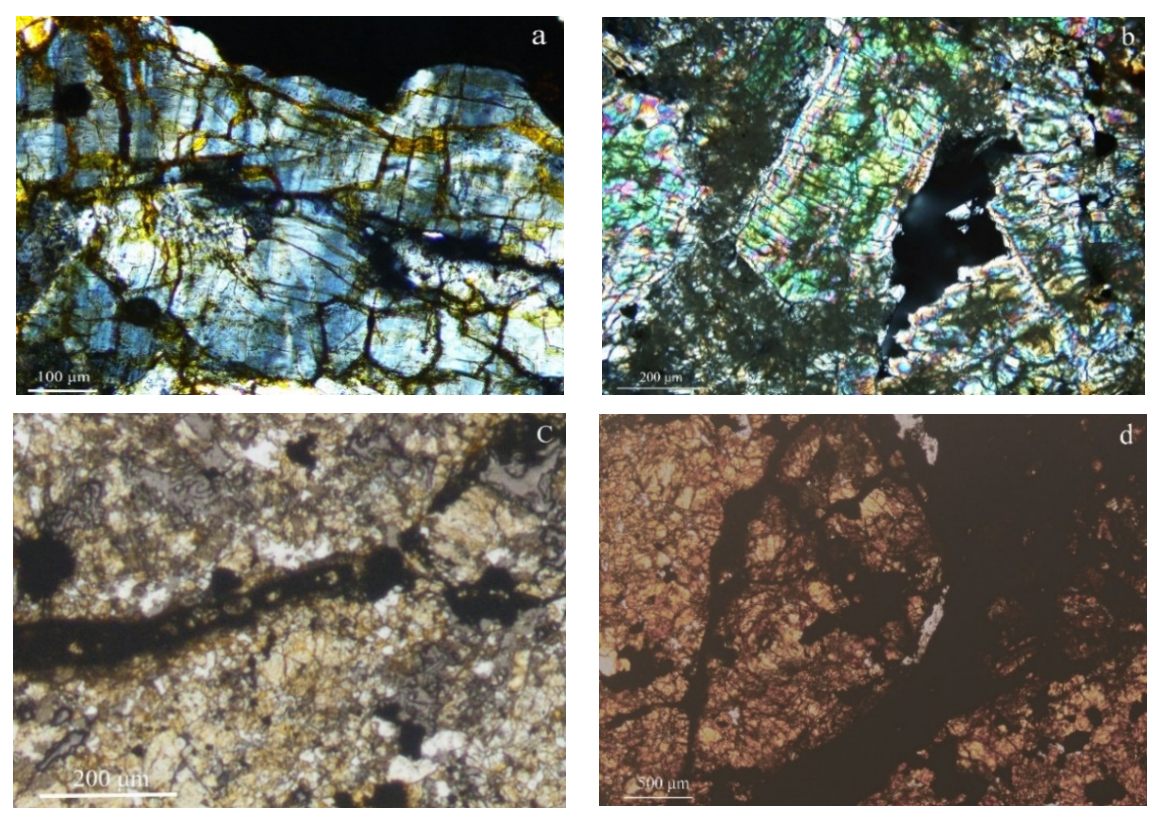

Figure 5. (a) Photomicrograph of olivine in GRV 020069 (S2) under cross-polarized light. The grey-colored grain in the center of the view exhibits undulatory extinction. (b) Photomicrograph of olivine in GRV 022244 (S3) under cross-polarized light. The grain of olivine has two sets of planar fractures. (c) Photomicrograph of shock-induced vein in GRV 020125(S4) under plane-polarized light. Some silicate clasts can be found in vein. (d) Photomicrograph of shock-induced vein in GRV 022194(S5) under plane-polarized light. Melt pockets and shock veins are pervasive.
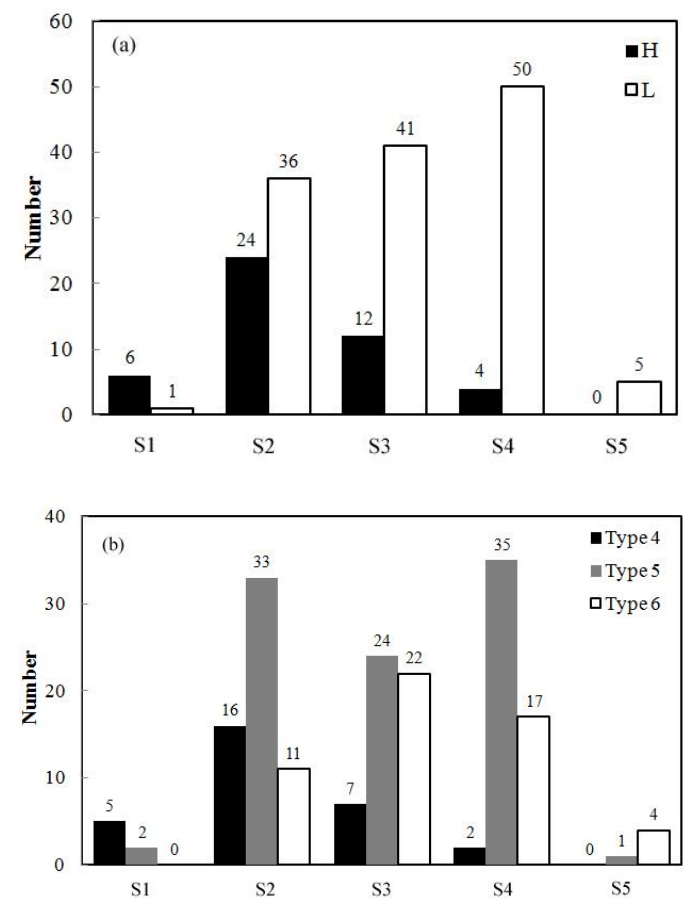

Figure 6. Histograms of shock degrees of Grove Mountain chondrites: (a) chemical groups, and (b) petrographic types. 
Since different groups of chondrites come from different parent bodies, the diverse distribution of frequencies of shock degrees between $\mathrm{H}$ and $\mathrm{L}$ groups may result from the different physical properties of the surfaces of their parent bodies [24]; for example, the thickness of the soil layer, the petrologic rock type on the surface, etc. As discussed above, a thick and porous regolith is not favorable to reserving high pressure and temperature conditions. An analogous case can be seen on the moon and on Mars. The former is covered by a layer of lunar regolith 2-10 $\mathrm{m}$ in depth, while Martian soil is not so abundant on the surface of Mars. Therefore, Martian meteorites have experienced a stronger shock metamorphism than the lunar meteorites [11,25-32].

Another aspect is that the frequency of shock degrees within different petrologic types (Figure 6b) reveals some variations. With increasing petrologic types, the frequency of the shock degrees S3, S4, and S5 increases. The shock degree S2 is the most abundant in type 4 meteorites, while the shock degrees S2 and S4 are the most abundant in type 5 meteorites, and S3 and S4 are the most abundant in type 6 meteorites. There is a lack of shock degrees S1 and S5 in petrologic type 6 and 4 meteorites, respectively. Stöffler et al. made the same observation: no S5 and S6 degrees were observed among type 4 ordinary chondrites [23]. The tendency that, between petrologic types and shock degrees, heavily shocked samples are most likely to be observed in highly petrologic chondrite types may be attributed to the different physical properties of all chondrite types in their unshocked state. High equilibrated samples (type $5 / 6$ chondrites) are essentially coherent nonporous rocks, in which the high pressures and temperatures are more easily retained for a longer time during a shock event, while type 4 chondrites are more porous and richer in volatiles which are more easily crushed upon impact, thereby releasing the high pressure.

\section{Conclusions}

We studied the petrography and mineral chemistry of 184 Grove Mountain equilibrated ordinary chondrites. Their chemical-petrographic types were assigned, including $46 \mathrm{H}$ groups $(22 \mathrm{H} 4,20 \mathrm{H} 5$, and four H6), 133 L groups (eight L4, 75 L5, and 50 L6), and five LL groups (four LL4 and one LL5). Some of these chondrites could be paired; however, both $\mathrm{H}$ and $\mathrm{L}$ group meteorites were affected.

The relative abundances of $\mathrm{H}, \mathrm{L}$, and LL are different for Grove Mountain meteorites when compared with those of Transcontinental Ridge meteorites. The Grove Mountain meteorites have smaller sizes (average mass of $67.9 \mathrm{~g}$ ) in comparison with the latter meteorites (average mass of $261.3 \mathrm{~g}$ ).

On the basis of the observed shock effects, the shock degrees of the 184 ordinary chondrites were classified. There are 10 with an S1 shock degree, 61 with S2, 54 with S3, 54 with S4, and five with S5. A comparison of the frequencies of shock degrees within different chemical groups shows a diverse frequency distribution of shock degrees between $\mathrm{H}$ and $\mathrm{L}$ groups, which may represent the difference between the physical properties of their parent body surfaces. Besides, it appears that the frequency of the shock degrees S3, S4, and S5 increases with increasing petrologic types.

Author Contributions: D.D. conceived and designed the experiments; D.D. and S.L. performed the experiments; D.D., S.L. and X.L. analyzed the data; D.D. wrote the paper, assisted by all other authors.

Funding: This research was funded by the National Natural Science Foundation of China (41673070 and 41503062 ).

Acknowledgments: Three anonymous reviewers are thanked for their constructive comments and suggestions which greatly improved the quality of this paper. We thank the Polar Research Institute of China for providing all of the samples in this study. The EPMA analysis of 92 meteorites were conducted by Dr. Shijie Li.

Conflicts of Interest: The authors declare no conflict of interest. 


\section{Appendix A}

Table A1. The major characteristics of 184 ordinary chondrites.

\begin{tabular}{|c|c|c|c|c|c|c|c|c|c|}
\hline \multirow{2}{*}{ Meteorites } & \multirow{2}{*}{ Found Location } & \multirow{2}{*}{ Type } & \multirow{2}{*}{ Weight (g) } & \multirow{2}{*}{$\begin{array}{c}\text { Opaque } \\
\text { Mineral (vol\%) }\end{array}$} & \multicolumn{2}{|c|}{ Olivine } & \multicolumn{2}{|c|}{ Low-Ca Pyroxene } & \multirow{2}{*}{ Shock Degrees } \\
\hline & & & & & Fa & PMD & Fs & PMD & \\
\hline GRV020007 & $\begin{array}{l}\mathrm{S} 73^{\circ} 05^{\prime} 23^{\prime \prime} \\
\mathrm{E} 75^{\circ} 11^{\prime} 22^{\prime \prime}\end{array}$ & $\mathrm{H} 4$ & 25.9 & 8.4 & 17.0 & 3.8 & 15.8 & 3.7 & S2 \\
\hline GRV020008 & $\begin{array}{l}\mathrm{S} 73^{\circ} 05^{\prime} 05^{\prime \prime} \\
\mathrm{E} 75^{\circ} 12^{\prime} 33^{\prime \prime}\end{array}$ & $\mathrm{H} 4$ & 6.2 & 4.5 & 18.0 & 1.1 & 16.1 & 1.6 & S2 \\
\hline GRV020042 & $\begin{array}{l}\mathrm{S} 73^{\circ} 00^{\prime} 23^{\prime \prime} \\
\mathrm{E} 75^{\circ} 11^{\prime} 32^{\prime \prime}\end{array}$ & $\mathrm{H} 4$ & 2.2 & 4.2 & 18.2 & 1.6 & 16.2 & 2.6 & S1 \\
\hline GRV020051 & $\begin{array}{l}\mathrm{S} 72^{\circ} 59^{\prime} 30^{\prime \prime} \\
\mathrm{E}^{\circ} 13^{\prime} 40^{\prime \prime}\end{array}$ & $\mathrm{H} 4$ & 1.4 & 4.0 & 19.5 & 1.2 & 17.4 & 2.1 & S2 \\
\hline GRV020066 & $\begin{array}{l}\mathrm{S} 72^{\circ} 59^{\prime} 57^{\prime \prime} \\
\mathrm{E} 75^{\circ} 14^{\prime} 20^{\prime \prime}\end{array}$ & $\mathrm{H} 4$ & 1.8 & 3.3 & 17.4 & 4.1 & 16.5 & 4.7 & S1 \\
\hline GRV020070 & $\begin{array}{l}572^{\circ} 59^{\prime} 57^{\prime \prime} \\
\text { E75 } 12^{\prime} 10^{\prime \prime}\end{array}$ & $\mathrm{H} 4$ & 7.9 & 6.0 & 18.4 & 0.8 & 16.4 & 1.6 & S3 \\
\hline GRV020074 & $\begin{array}{l}\mathrm{S}_{72}^{\circ} 59^{\prime} 45^{\prime \prime} \\
\mathrm{E}^{\circ} 5^{\circ} 12^{\prime} 35^{\prime \prime}\end{array}$ & $\mathrm{H} 4$ & 1.5 & 8.4 & 19.9 & 6.4 & 17.5 & 4.0 & S3 \\
\hline GRV020088 & $\begin{array}{l}\mathrm{S} 73^{\circ} 00^{\prime} 13^{\prime \prime} \\
\mathrm{E} 75^{\circ} 15^{\prime} 10^{\prime \prime}\end{array}$ & $\mathrm{H} 4$ & 3.0 & 5.1 & 18.6 & 1.7 & 17.0 & 1.3 & S2 \\
\hline GRV020091 & $\begin{array}{l}\mathrm{S} 72^{\circ} 59^{\prime} 45^{\prime \prime} \\
\mathrm{E}^{\circ} 5^{\circ} 13^{\prime} 39^{\prime \prime}\end{array}$ & $\mathrm{H} 4$ & 5.3 & 6.1 & 18.2 & 1.0 & 16.4 & 0.6 & S2 \\
\hline GRV020108 & $\begin{array}{l}\mathrm{S} 72^{\circ} 58^{\prime} 49^{\prime \prime} \\
\mathrm{E}^{\circ} 15^{\prime} 20^{\prime \prime}\end{array}$ & $\mathrm{H} 4$ & 5.8 & 1.4 & 18.5 & 1.0 & 16.5 & 1.6 & $\mathrm{~S} 1$ \\
\hline GRV020109 & $\begin{array}{l}\mathrm{S}^{\circ} 2^{\circ} 58^{\prime} 49^{\prime \prime} \\
\mathrm{E} 75^{\circ} 15^{\prime} 17^{\prime \prime}\end{array}$ & $\mathrm{H} 4$ & 2.0 & 5.4 & 18.6 & 0.6 & 16.5 & 1.6 & S2 \\
\hline GRV020110 & $\begin{array}{l}\mathrm{S} 72^{\circ} 58^{\prime} 53^{\prime \prime} \\
\text { E75 } 14^{\prime} 59^{\prime \prime}\end{array}$ & $\mathrm{H} 4$ & 3.1 & 7.3 & 18.7 & 1.5 & 16.6 & 1.1 & S2 \\
\hline GRV020113 & $\begin{array}{l}S 72^{\circ} 58^{\prime} 48^{\prime \prime} \\
\mathrm{E} 75^{\circ} 15^{\prime} 36^{\prime \prime}\end{array}$ & $\mathrm{H} 4$ & 1.3 & 4.8 & 19.5 & 8.6 & 17.5 & 5.4 & S2 \\
\hline GRV020130 & $\begin{array}{l}\mathrm{S} 72^{\circ} 58^{\prime} 36^{\prime \prime} \\
\mathrm{E}^{\circ} 5^{\circ} 15^{\prime} 37^{\prime \prime}\end{array}$ & $\mathrm{H} 4$ & 139.7 & 3.3 & 18.6 & 0.8 & 16.6 & 1.7 & S1 \\
\hline GRV021492 & $\begin{array}{l}\mathrm{S} 72^{\circ} 58^{\prime} 01^{\prime \prime} \\
\mathrm{E} 75^{\circ} 16^{\prime} 24^{\prime \prime}\end{array}$ & $\mathrm{H} 4$ & 211.2 & 10.0 & 18.1 & 1.3 & 16.0 & 0.7 & S2 \\
\hline GRV021508 & $\begin{array}{l}\mathrm{S} 72^{\circ} 56^{\prime} 47^{\prime \prime} \\
\mathrm{E} 75^{\circ} 17^{\prime} 00^{\prime \prime}\end{array}$ & $\mathrm{H} 4$ & 278.2 & 7.4 & 20.6 & 1.2 & 18.1 & 6.2 & S3 \\
\hline GRV021549 & $\begin{array}{l}\mathrm{S}{ }^{\circ} 56^{\prime} 05^{\prime \prime} \\
\mathrm{E} 75^{\circ} 19^{\prime} 18^{\prime \prime}\end{array}$ & $\mathrm{H} 4$ & 16.3 & 1.5 & 17.6 & 1.4 & 17.4 & 3.2 & S2 \\
\hline GRV021550 & $\begin{array}{l}S 72^{\circ} 56^{\prime} 05^{\prime \prime} \\
\text { E75 } 5^{\circ} 19^{\prime} 13^{\prime \prime}\end{array}$ & $\mathrm{H} 4$ & 18.6 & 4.3 & 19.5 & 4.2 & 16.7 & 2.0 & S2 \\
\hline GRV021566 & $\begin{array}{l}S 72^{\circ} 56^{\prime} 18^{\prime \prime} \\
\mathrm{E} 75^{\circ} 17^{\prime} 23^{\prime \prime}\end{array}$ & $\mathrm{H} 4$ & 13.5 & 0.8 & 19.0 & 2.2 & 17.3 & 2.6 & S2 \\
\hline GRV021569 & $\begin{array}{l}\mathrm{S} 72^{\circ} 56^{\prime} 25^{\prime \prime} \\
\mathrm{E} 75^{\circ} 17^{\prime} 09^{\prime \prime}\end{array}$ & $\mathrm{H} 4$ & 19.7 & 1.7 & 19.9 & 2.2 & 17.5 & 1.9 & S2 \\
\hline GRV021576 & $\begin{array}{l}\mathrm{S} 72^{\circ} 57^{\prime} 50^{\prime \prime} \\
\mathrm{E} 75^{\circ} 12^{\prime} 58^{\prime \prime}\end{array}$ & $\mathrm{H} 4$ & 105.9 & 3.4 & 18.7 & 1.1 & 16.9 & 0.9 & $\mathrm{~S} 1$ \\
\hline GRV021593 & $\begin{array}{l}S 72^{\circ} 51^{\prime} 16^{\prime \prime} \\
\mathrm{E}^{\circ} 15^{\circ} 12^{\prime} 39^{\prime \prime}\end{array}$ & $\mathrm{H} 4$ & 28.1 & 6.0 & 19.1 & 1.6 & 16.9 & 1.8 & S4 \\
\hline GRV020023 & $\begin{array}{l}\mathrm{S} 73^{\circ} 05^{\prime} 09^{\prime \prime} \\
\mathrm{E} 75^{\circ} 12^{\prime} 30^{\prime \prime}\end{array}$ & H5 & 2.7 & 6.1 & 18.4 & 0.9 & 17.0 & 3.2 & S3 \\
\hline GRV020071 & $\begin{array}{l}\text { S72 } 52^{\circ} 9^{\prime} 56^{\prime \prime} \\
\text { E75 } 15^{\circ} 15^{\prime \prime}\end{array}$ & H5 & 4.5 & 2.7 & 18.2 & 1.7 & 16.6 & 0.8 & S2 \\
\hline GRV020076 & $\begin{array}{l}S 72^{\circ} 59^{\prime} 43^{\prime \prime} \\
\mathrm{E} 75^{\circ} 12^{\prime} 16^{\prime \prime}\end{array}$ & H5 & 37.3 & 4.5 & 18.9 & 3.9 & 16.6 & 3.8 & S3 \\
\hline GRV020077 & $\begin{array}{l}\mathrm{S}^{\circ} 2^{\circ} 59^{\prime} 40^{\prime \prime} \\
\mathrm{E} 75^{\circ} 12^{\prime} 18^{\prime \prime}\end{array}$ & $\mathrm{H} 5$ & 1.3 & 3.2 & 20.0 & 3.6 & 17.6 & 2.3 & S3 \\
\hline GRV020087 & $\begin{array}{l}\mathrm{S}^{\circ} 03^{\circ} 00^{\prime} 08^{\prime \prime} \\
\mathrm{E} 75^{\circ} 16^{\prime} 59^{\prime \prime}\end{array}$ & $\mathrm{H} 5$ & 2.1 & 2.4 & 18.4 & 1.8 & 16.6 & 1.4 & S2 \\
\hline GRV020089 & $\begin{array}{l}\mathrm{S} 73^{\circ} 00^{\prime} 13^{\prime \prime} \\
\mathrm{E}^{\circ} 5^{\circ} 15^{\prime} 05^{\prime \prime}\end{array}$ & H5 & 4.6 & 8.5 & 18.7 & 1.3 & 16.9 & 1.1 & S2 \\
\hline GRV020092 & $\begin{array}{l}\mathrm{S} 72^{\circ} 59^{\prime} 45^{\prime \prime} \\
\mathrm{E} 75^{\circ} 12^{\prime} 24^{\prime \prime}\end{array}$ & H5 & 1.3 & 5.0 & 18.4 & 2.3 & 16.9 & 0.6 & S4 \\
\hline GRV020097 & $\begin{array}{l}\mathrm{S}_{72^{\circ}} 59^{\prime} 40^{\prime \prime} \\
\mathrm{E} 75^{\circ} 12^{\prime} 15^{\prime \prime}\end{array}$ & H5 & 131.2 & 5.5 & 19.5 & 2.8 & 17.7 & 7.8 & S2 \\
\hline GRV020123 & $\begin{array}{l}\mathrm{S} 72^{\circ} 58^{\prime} 40^{\prime \prime} \\
\mathrm{E} 75^{\circ} 15^{\prime} 36^{\prime \prime}\end{array}$ & $\mathrm{H} 5$ & 3.4 & 6.2 & 19.2 & 1.2 & 17.2 & 1.3 & S1 \\
\hline GRV020153 & $\begin{array}{l}\mathrm{S}^{\circ} 52^{\circ} 50^{\prime \prime} \\
\mathrm{E}^{\circ} 5^{\circ} 15^{\prime} 51^{\prime \prime}\end{array}$ & $\mathrm{H} 5$ & 1.6 & 3.4 & 20.1 & 1.6 & 17.6 & 1.6 & S2 \\
\hline GRV020174 & $\begin{array}{l}\mathrm{S}^{\circ} 58^{\circ} 43^{\prime \prime} \\
\mathrm{E}^{\circ} 15^{\prime} 37^{\prime \prime}\end{array}$ & H5 & 1.3 & 3.7 & 19.9 & 1.5 & 17.6 & 3.4 & S3 \\
\hline GRV021480 & $\begin{array}{l}\mathrm{S} 72^{\circ} 56^{\prime} 07^{\prime \prime} \\
\mathrm{E}^{\circ}{ }^{\circ} 19^{\prime} 29^{\prime \prime}\end{array}$ & $\mathrm{H} 5$ & 12.9 & 4.3 & 18.3 & 3.6 & 15.9 & 3.8 & S3 \\
\hline GRV021517 & $\begin{array}{l}{\mathrm{S} 72^{\circ}}^{\circ} 6^{\prime} 10^{\prime \prime} \\
\mathrm{E} 75^{\circ} 18^{\prime} 49^{\prime \prime}\end{array}$ & H5 & 96.4 & 4.0 & 18.9 & 1.3 & 17.0 & 2.0 & S2 \\
\hline
\end{tabular}


Table A1. Cont.

\begin{tabular}{|c|c|c|c|c|c|c|c|c|c|}
\hline \multirow{2}{*}{ Meteorites } & \multirow{2}{*}{ Found Location } & \multirow{2}{*}{ Type } & \multirow{2}{*}{ Weight (g) } & \multirow{2}{*}{$\begin{array}{c}\text { Opaque } \\
\text { Mineral (vol\%) }\end{array}$} & \multicolumn{2}{|c|}{ Olivine } & \multicolumn{2}{|c|}{ Low-Ca Pyroxene } & \multirow{2}{*}{ Shock Degrees } \\
\hline & & & & & $\mathrm{Fa}$ & PMD & Fs & PMD & \\
\hline GRV021518 & $\begin{array}{l}\mathrm{S}^{\circ} 52^{\circ} 11^{\prime \prime} \\
\mathrm{E}^{\circ} 18^{\prime} 51^{\prime \prime}\end{array}$ & H5 & 54.1 & 5.4 & 18.9 & 0.8 & 16.5 & 2.2 & S2 \\
\hline GRV021564 & $\begin{array}{l}S 72^{\circ} 56^{\prime} 03^{\prime \prime} \\
\mathrm{E} 75^{\circ} 19^{\prime} 20^{\prime \prime}\end{array}$ & $\mathrm{H} 5$ & 13.7 & 5.0 & 18.4 & 3.6 & 16.3 & 2.7 & S2 \\
\hline GRV021589 & $\begin{array}{l}S 72^{\circ} 57^{\prime} 57^{\prime \prime} \\
\mathrm{E} 75^{\circ} 13^{\prime} 48^{\prime \prime}\end{array}$ & H5 & 67.4 & 7.0 & 19.2 & 3.2 & 18.4 & 6.3 & S3 \\
\hline GRV021590 & $\begin{array}{l}S 72^{\circ} 56^{\prime} 08^{\prime \prime} \\
\mathrm{E} 75^{\circ} 17^{\prime} 54^{\prime \prime}\end{array}$ & H5 & 16.5 & 3.9 & 19.2 & 1.2 & 16.8 & 2.3 & S3 \\
\hline GRV021611 & $\begin{array}{l}\mathrm{S} 72^{\circ} 46^{\prime} 31^{\prime \prime} \\
\mathrm{E} 75^{\circ} 19^{\prime} 29^{\prime \prime}\end{array}$ & H5 & 26.7 & 3.3 & 18.0 & 1.1 & 16.0 & 0.5 & S2 \\
\hline GRV021715 & $\begin{array}{l}572^{\circ} 47^{\prime} 24^{\prime \prime} \\
\text { E75 } 17^{\prime} 47^{\prime \prime}\end{array}$ & H5 & 1.5 & 1.2 & 17.4 & 3.9 & 15.4 & 1.9 & S4 \\
\hline GRV021795 & $\begin{array}{l}S 72^{\circ} 46^{\prime} 26^{\prime \prime} \\
\text { E75 } 5^{\circ} 19^{\prime} 26^{\prime \prime}\end{array}$ & $\mathrm{H} 5$ & 11.8 & 3.5 & 18.5 & 0.7 & 16.6 & 0.9 & S2 \\
\hline GRV020072 & $\begin{array}{l}S 72^{\circ} 59^{\prime} 54^{\prime \prime} \\
\text { E75 } 11^{\circ} 11^{\prime} 45^{\prime \prime}\end{array}$ & H6 & 13.0 & 3.7 & 20.6 & 1.9 & 18.5 & 5.2 & S3 \\
\hline GRV020093 & $\begin{array}{l}\mathrm{S}^{\circ} 52^{\circ} 9^{\prime} 44^{\prime \prime} \\
\mathrm{E}^{\circ} 5^{\circ} 12^{\prime} 23^{\prime \prime}\end{array}$ & $\mathrm{H} 6$ & 1.1 & 9.0 & 19.9 & 1.5 & 17.1 & 1.5 & S3 \\
\hline GRV020098 & $\begin{array}{l}S 72^{\circ} 59^{\prime} 40^{\prime \prime} \\
\text { E75 } 5^{\circ} 12^{\prime} 16^{\prime \prime}\end{array}$ & H6 & 122.7 & 2.9 & 21.0 & 8.9 & 17.8 & 3.4 & S2 \\
\hline GRV021522 & $\begin{array}{l}\mathrm{S}^{\circ} 2^{\circ} 57^{\prime} 34^{\prime \prime} \\
\mathrm{E} 75^{\circ} 14^{\prime} 13^{\prime \prime}\end{array}$ & H6 & 1.2 & 6.6 & 17.3 & 1.7 & 15.6 & 2.5 & S4 \\
\hline GRV020038 & $\begin{array}{l}\mathrm{S} 73^{\circ} 08^{\prime} 37^{\prime \prime} \\
\mathrm{E} 75^{\circ} 03^{\prime} 27^{\prime \prime}\end{array}$ & L4 & 25.6 & 3.1 & 25.7 & 0.8 & 22.0 & 0.8 & S2 \\
\hline GRV020049 & $\begin{array}{l}S 72^{\circ} 59^{\prime} 40^{\prime \prime} \\
\mathrm{E} 75^{\circ} 12^{\prime} 34^{\prime \prime}\end{array}$ & L4 & 1.2 & 4.2 & 25.1 & 2.1 & 21.2 & 1.4 & S2 \\
\hline GRV021643 & $\begin{array}{l}S 72^{\circ} 46^{\prime} 22^{\prime \prime} \\
\text { E75 } 25^{\circ} 0^{\prime} 44^{\prime \prime}\end{array}$ & L4 & 12.8 & 4.7 & 24.0 & 1.3 & 20.4 & 1.3 & S2 \\
\hline GRV021654 & $\begin{array}{l}\mathrm{S}_{2}^{\circ} 46^{\prime} 24^{\prime \prime} \\
\mathrm{E}^{\circ} 5^{\circ} 19^{\prime} 55^{\prime \prime}\end{array}$ & $\mathrm{L} 4$ & 16.6 & 3.0 & 25.6 & 1.8 & 21.9 & 2.9 & S3 \\
\hline GRV021668 & $\begin{array}{l}\mathrm{S} 72^{\circ} 46^{\prime} 43^{\prime \prime} \\
\mathrm{E}^{\circ} 5^{\circ} 19^{\prime} 48^{\prime \prime}\end{array}$ & L4 & 88.5 & 3.2 & 25.1 & 1.1 & 21.6 & 2.6 & S3 \\
\hline GRV021726 & $\begin{array}{l}\mathrm{S} 72^{\circ} 47^{\prime} 24^{\prime \prime} \\
\mathrm{E} 75^{\circ} 17^{\prime} 22^{\prime \prime}\end{array}$ & L4 & 11.2 & 4.0 & 25.3 & 1.2 & 21.5 & 3.0 & S3 \\
\hline GRV021800 & $\begin{array}{l}572^{\circ} 46^{\prime} 24^{\prime \prime} \\
\text { E75 } 20^{\prime} 02^{\prime \prime}\end{array}$ & L4 & 14.1 & 1.2 & 25.2 & 1.7 & 21.6 & 2.9 & S3 \\
\hline GRV022221 & $\begin{array}{l}\mathrm{S} 72^{\circ} 46^{\prime} 42^{\prime \prime} \\
\mathrm{E} 75^{\circ} 19^{\prime} 15^{\prime \prime}\end{array}$ & L4 & 29.1 & 3.3 & 25.0 & 0.9 & 21.1 & 1.5 & S4 \\
\hline GRV020040 & $\begin{array}{l}S 73^{\circ} 08^{\prime} 05^{\prime \prime} \\
\mathrm{E} 75^{\circ} 02^{\prime} 34^{\prime \prime}\end{array}$ & L5 & 31.7 & 6.2 & 24.4 & 1.4 & 21.0 & 1.9 & S2 \\
\hline GRV020068 & $\begin{array}{l}S 72^{\circ} 59^{\prime} 42^{\prime \prime} \\
\mathrm{E} 75^{\circ} 12^{\prime} 21^{\prime \prime}\end{array}$ & L5 & 623.8 & 3.5 & 24.6 & 0.6 & 21.2 & 1.2 & S4 \\
\hline GRV020069 & $\begin{array}{l}S 72^{\circ} 59^{\prime} 44^{\prime \prime} \\
\text { E75 } 5^{\circ} 12^{\prime} 28^{\prime \prime}\end{array}$ & L5 & 171.5 & 5.1 & 24.4 & 1.5 & 20.8 & 0.7 & S2 \\
\hline GRV020096 & $\begin{array}{l}\mathrm{S} 72^{\circ} 59^{\prime} 49^{\prime \prime} \\
\mathrm{E} 75^{\circ} 12^{\prime} 22^{\prime \prime}\end{array}$ & L5 & 1.8 & 0.9 & 24.7 & 4.9 & 20.2 & 20.2 & S3 \\
\hline GRV020107 & $\begin{array}{l}\text { S72 } 52^{\circ} 48^{\prime \prime} \\
\text { E75 } 15^{\circ} 13^{\prime} 23^{\prime \prime}\end{array}$ & L5 & 3.7 & 1.8 & 24.2 & 0.9 & 20.7 & 0.8 & S4 \\
\hline GRV020125 & $\begin{array}{l}S 72^{\circ} 58^{\prime} 46^{\prime \prime} \\
\mathrm{E} 75^{\circ} 15^{\prime} 37^{\prime \prime}\end{array}$ & L5 & 2.1 & 3.9 & 24.9 & 0.6 & 21.4 & 1.1 & S4 \\
\hline GRV020127 & $\begin{array}{l}S 72^{\circ} 58^{\prime} 50^{\prime \prime} \\
\mathrm{E} 5^{\circ} 15^{\prime} 45^{\prime \prime}\end{array}$ & L5 & 6.8 & 1.6 & 24.7 & 1.9 & 18.7 & 1.3 & S1 \\
\hline GRV020154 & $\begin{array}{l}\mathrm{S} 72^{\circ} 58^{\prime} 51^{\prime \prime} \\
\mathrm{E}^{\circ} 5^{\circ} 15^{\prime} 40^{\prime \prime}\end{array}$ & L5 & 1.5 & 2.9 & 26.6 & 2.9 & 22.0 & 1.0 & S2 \\
\hline GRV021495 & $\begin{array}{l}572^{\circ} 56^{\prime} 48^{\prime \prime} \\
\text { E75 } 18^{\prime} 21^{\prime \prime}\end{array}$ & L5 & 43.7 & 3.9 & 24.2 & 1.1 & 20.8 & 1.1 & S4 \\
\hline GRV021499 & $\begin{array}{l}\mathrm{S} 72^{\circ} 56^{\prime} 35^{\prime \prime} \\
\mathrm{E} 75^{\circ} 17^{\prime} 48^{\prime \prime}\end{array}$ & L5 & 57.1 & 3.9 & 23.1 & 0.7 & 19.7 & 0.7 & S2 \\
\hline GRV021500 & $\begin{array}{l}\mathrm{S} 72^{\circ} 56^{\prime} 57^{\prime \prime} \\
\mathrm{E} 75^{\circ} 17^{\prime} 33^{\prime \prime}\end{array}$ & L5 & 12.8 & 3.9 & 23.7 & 1.1 & 20.8 & 3.0 & S4 \\
\hline GRV021501 & $\begin{array}{l}S 72^{\circ} 56^{\prime} 40^{\prime \prime} \\
\mathrm{E} 75^{\circ} 17^{\prime} 55^{\prime \prime}\end{array}$ & L5 & 17.4 & 2.5 & 24.0 & 1.5 & 20.7 & 0.8 & S3 \\
\hline GRV021548 & $\begin{array}{l}S 72^{\circ} 57^{\prime} 46^{\prime \prime} \\
\mathrm{E} 75^{\circ} 14^{\prime} 46^{\prime \prime}\end{array}$ & L5 & 31.8 & 2.4 & 24.1 & 0.7 & 20.9 & 1.3 & S2 \\
\hline GRV021582 & $\begin{array}{l}\mathrm{S}^{\circ} 52^{\circ} 57^{\prime} 47^{\prime \prime} \\
\mathrm{E} 75^{\circ} 13^{\prime} 28^{\prime \prime}\end{array}$ & L5 & 14.2 & 5.3 & 24.2 & 2.7 & 20.5 & 1.3 & S4 \\
\hline GRV021586 & $\begin{array}{l}S 72^{\circ} 57^{\prime} 43^{\prime \prime} \\
\mathrm{E} 75^{\circ} 15^{\prime} 20^{\prime \prime}\end{array}$ & L5 & 11.6 & 3.4 & 24.4 & 1.5 & 21.0 & 1.1 & S2 \\
\hline GRV021587 & $\begin{array}{l}\mathrm{S} 72^{\circ} 57^{\prime} 50^{\prime \prime} \\
\mathrm{E} 75^{\circ} 13^{\prime} 31^{\prime \prime}\end{array}$ & L5 & 31.3 & 3.7 & 24.2 & 2.7 & 20.5 & 1.0 & S2 \\
\hline GRV021614 & $\begin{array}{l}S 72^{\circ} 46^{\prime} 24^{\prime \prime} \\
\text { E75 } 19^{\prime} 16^{\prime \prime}\end{array}$ & L5 & 17.3 & 3.1 & 23.4 & 1.1 & 20.2 & 1.0 & S4 \\
\hline GRV021651 & $\begin{array}{l}\mathrm{S} 72^{\circ} 46^{\prime} 35^{\prime \prime} \\
\mathrm{E}^{\circ} 5^{\circ} 20^{\prime} 52^{\prime \prime}\end{array}$ & L5 & 35.2 & 4.1 & 24.6 & 0.7 & 21.1 & 0.8 & S3 \\
\hline GRV021652 & $\begin{array}{l}\mathrm{S} 72^{\circ} 46^{\prime} 28^{\prime \prime} \\
\mathrm{E}^{\circ} 5^{\circ} 0^{\prime} 03^{\prime \prime}\end{array}$ & L5 & 57.9 & 2.8 & 25.8 & 2.2 & 21.6 & 2.9 & S3 \\
\hline
\end{tabular}


Table A1. Cont.

\begin{tabular}{|c|c|c|c|c|c|c|c|c|c|}
\hline \multirow{2}{*}{ Meteorites } & \multirow{2}{*}{ Found Location } & \multirow{2}{*}{ Type } & \multirow{2}{*}{ Weight (g) } & \multirow{2}{*}{$\begin{array}{c}\text { Opaque } \\
\text { Mineral (vol\%) }\end{array}$} & \multicolumn{2}{|c|}{ Olivine } & \multicolumn{2}{|c|}{ Low-Ca Pyroxene } & \multirow{2}{*}{ Shock Degrees } \\
\hline & & & & & Fa & PMD & Fs & PMD & \\
\hline GRV021669 & $\begin{array}{l}\mathrm{S}^{\circ} 2^{\circ} 46^{\prime} 42^{\prime \prime} \\
\mathrm{E} 75^{\circ} 19^{\prime} 49^{\prime \prime}\end{array}$ & L5 & 406.1 & 2.4 & 26.0 & 2.6 & 22.1 & 2.5 & S3 \\
\hline GRV021670 & $\begin{array}{l}\mathrm{S} 72^{\circ} 46^{\prime} 43^{\prime \prime} \\
\mathrm{E}^{\circ} 5^{\circ} 19^{\prime} 54^{\prime \prime}\end{array}$ & L5 & 282.4 & 3.0 & 26.0 & 2.3 & 21.9 & 2.6 & S3 \\
\hline GRV021724 & $\begin{array}{l}\mathrm{S} 72^{\circ} 47^{\prime} 23^{\prime \prime} \\
\mathrm{E}^{\circ} 5^{\circ} 17^{\prime} 50^{\prime \prime}\end{array}$ & L5 & 22.0 & 3.3 & 23.4 & 1.4 & 20.2 & 0.9 & S4 \\
\hline GRV021725 & $\begin{array}{l}\mathrm{S} 72^{\circ} 47^{\prime} 23^{\prime \prime} \\
\mathrm{E}^{\circ} 5^{\circ} 17^{\prime} 31^{\prime \prime}\end{array}$ & L5 & 25.0 & 3.3 & 26.1 & 2.9 & 21.8 & 3.4 & S2 \\
\hline GRV021785 & $\begin{array}{l}\mathrm{S} 72^{\circ} 46^{\prime} 30^{\prime \prime} \\
\mathrm{E}^{\circ} 20^{\prime} 20^{\prime \prime}\end{array}$ & L5 & 71.7 & 2.9 & 25.6 & 0.9 & 21.6 & 3.2 & S3 \\
\hline GRV021794 & $\begin{array}{l}\mathrm{S} 72^{\circ} 46^{\prime} 25^{\prime \prime} \\
\mathrm{E}^{\circ} 5^{\circ} 19^{\prime} 23^{\prime \prime}\end{array}$ & L5 & 44.5 & 0.2 & 24.2 & 1.9 & 20.9 & 0.5 & S3 \\
\hline GRV021801 & $\begin{array}{l}\mathrm{S} 72^{\circ} 46^{\prime} 24^{\prime \prime} \\
\mathrm{E}^{\circ} 20^{\prime} 03^{\prime \prime}\end{array}$ & L5 & 28.1 & 1.6 & 24.9 & 1.9 & 21.8 & 2.3 & S2 \\
\hline GRV021802 & $\begin{array}{l}\mathrm{S} 72^{\circ} 46^{\prime} 24^{\prime \prime} \\
\mathrm{E}^{\circ} 25^{\circ} 04^{\prime \prime}\end{array}$ & L5 & 175.0 & 2.4 & 25.7 & 1.0 & 21.6 & 2.2 & S2 \\
\hline GRV021803 & $\begin{array}{l}\mathrm{S}^{\circ} 42^{\prime} 27^{\prime \prime} \\
\mathrm{E}^{\circ} 20^{\prime} 20^{\prime \prime}\end{array}$ & L5 & 115.9 & 5.7 & 25.4 & 1.9 & 21.4 & 3.3 & S4 \\
\hline GRV021804 & $\begin{array}{l}\mathrm{S} 72^{\circ} 46^{\prime} 30^{\prime \prime} \\
\mathrm{E}^{\circ} 5^{\circ} 19^{\prime} 46^{\prime \prime}\end{array}$ & L5 & 46.1 & 1.7 & 25.6 & 1.8 & 21.5 & 2.9 & S4 \\
\hline GRV022024 & $\begin{array}{l}\mathrm{S} 72^{\circ} 47^{\prime} 01^{\prime \prime} \\
\mathrm{E} 75^{\circ} 17^{\prime} 58^{\prime \prime}\end{array}$ & L5 & 105.9 & 1.8 & 23.4 & 2.1 & 20.1 & 0.8 & S2 \\
\hline GRV022026 & $\begin{array}{l}\mathrm{S} 72^{\circ} 47^{\prime} 00^{\prime \prime} \\
\mathrm{E} 75^{\circ} 17^{\prime} 48^{\prime \prime}\end{array}$ & L5 & 73.3 & 3.3 & 23.5 & 1.4 & 20.2 & 2.0 & S2 \\
\hline GRV022027 & $\begin{array}{l}\mathrm{S} 72^{\circ} 46^{\prime} 59^{\prime \prime} \\
\mathrm{E} 75^{\circ} 17^{\prime} 54^{\prime \prime}\end{array}$ & L5 & 169.7 & 3.3 & 23.4 & 1.2 & 20.1 & 1.1 & S4 \\
\hline GRV022028 & $\begin{array}{l}\mathrm{S}^{\circ} 2^{\circ} 46^{\prime} 57^{\prime \prime} \\
\mathrm{E} 75^{\circ} 18^{\prime} 01^{\prime \prime}\end{array}$ & L5 & 244.9 & 2.1 & 23.9 & 1.6 & 20.4 & 1.7 & S2 \\
\hline GRV022038 & $\begin{array}{l}\mathrm{S} 72^{\circ} 46^{\prime} 54^{\prime \prime} \\
\mathrm{E}^{\circ} 18^{\prime} 10^{\prime \prime}\end{array}$ & L5 & 1012.0 & 3.5 & 25.2 & 1.3 & 22.2 & 3.6 & S3 \\
\hline GRV022039 & $\begin{array}{l}\mathrm{S} 72^{\circ} 46^{\prime} 43^{\prime \prime} \\
\mathrm{E} 75^{\circ} 18^{\prime} 55^{\prime \prime}\end{array}$ & L5 & 160.7 & 2.0 & 24.8 & 1.0 & 20.9 & 1.8 & S3 \\
\hline GRV022040 & $\begin{array}{l}\mathrm{S} 72^{\circ} 46^{\prime} 43^{\prime \prime} \\
\mathrm{E} 75^{\circ} 18^{\prime} 55^{\prime \prime}\end{array}$ & L5 & 589.5 & 2.8 & 24.8 & 2.0 & 21.5 & 3.9 & S3 \\
\hline GRV022041 & $\begin{array}{l}\mathrm{S}^{\circ} 2^{\circ} 46^{\prime} 43^{\prime \prime} \\
\mathrm{E} 75^{\circ} 18^{\prime} 55^{\prime \prime}\end{array}$ & L5 & 96.4 & 2.2 & 25.6 & 1.5 & 21.5 & 1.6 & S4 \\
\hline GRV022042 & $\begin{array}{l}\mathrm{S} 72^{\circ} 46^{\prime} 43^{\prime \prime} \\
\mathrm{E}^{\circ} 18^{\prime} 55^{\prime \prime}\end{array}$ & L5 & 218.1 & 2.5 & 26.7 & 2.9 & 21.5 & 3.4 & S2 \\
\hline GRV022126 & $\begin{array}{l}\mathrm{S} 72^{\circ} 46^{\prime} 44^{\prime \prime} \\
\mathrm{E} 75^{\circ} 18^{\prime} 49^{\prime \prime}\end{array}$ & L5 & 48.0 & 3.1 & 23.5 & 1.0 & 20.5 & 2.6 & S2 \\
\hline GRV022127 & $\begin{array}{l}\mathrm{S} 72^{\circ} 46^{\prime} 44^{\prime \prime} \\
\mathrm{E}^{\circ} 18^{\prime} 49^{\prime \prime}\end{array}$ & L5 & 39.2 & 2.4 & 23.9 & 1.3 & 20.7 & 2.6 & S4 \\
\hline GRV022128 & $\begin{array}{l}\mathrm{S}^{\circ} 2^{\circ} 46^{\prime} 44^{\prime \prime} \\
\mathrm{E} 75^{\circ} 18^{\prime} 49^{\prime \prime}\end{array}$ & L5 & 31.1 & 2.8 & 23.6 & 1.8 & 20.4 & 0.9 & S4 \\
\hline GRV022141 & $\begin{array}{l}\mathrm{S} 72^{\circ} 46^{\prime} 44^{\prime \prime} \\
\mathrm{E} 75^{\circ} 18^{\prime} 49^{\prime \prime}\end{array}$ & L5 & 26.6 & 2.3 & 23.6 & 2.4 & 20.5 & 2.1 & S4 \\
\hline GRV022142 & $\begin{array}{l}\mathrm{S} 72^{\circ} 46^{\prime} 44^{\prime \prime} \\
\mathrm{E}^{\circ} 18^{\prime} 49^{\prime \prime}\end{array}$ & L5 & 23.3 & 4.9 & 24.0 & 3.5 & 20.8 & 2.6 & S4 \\
\hline GRV022143 & $\begin{array}{l}\mathrm{S} 72^{\circ} 46^{\prime} 44^{\prime \prime} \\
\mathrm{E}^{\circ} 18^{\prime} 49^{\prime \prime}\end{array}$ & L5 & 14.7 & 3.4 & 23.4 & 1.6 & 20.1 & 0.7 & S4 \\
\hline GRV022146 & $\begin{array}{l}\mathrm{S} 72^{\circ} 46^{\prime} 44^{\prime \prime} \\
\mathrm{E}^{\circ} 18^{\prime} 49^{\prime \prime}\end{array}$ & L5 & 20.7 & 2.6 & 23.7 & 2.8 & 20.4 & 1.0 & S4 \\
\hline GRV022150 & $\begin{array}{l}\mathrm{S} 72^{\circ} 46^{\prime} 44^{\prime \prime} \\
\mathrm{E}^{\circ} 18^{\prime} 49^{\prime \prime}\end{array}$ & L5 & 14.3 & 4.2 & 23.7 & 12.4 & 18.2 & 4.4 & S4 \\
\hline GRV022151 & $\begin{array}{l}\mathrm{S} 72^{\circ} 46^{\prime} 44^{\prime \prime} \\
\mathrm{E}^{\circ} 18^{\prime} 49^{\prime \prime}\end{array}$ & L5 & 12.5 & 3.8 & 25.2 & 1.4 & 22.3 & 2.4 & S4 \\
\hline GRV022159 & $\begin{array}{l}\mathrm{S} 72^{\circ} 46^{\prime} 54^{\prime \prime} \\
\mathrm{E}^{\circ} 5^{\circ} 18^{\prime} 14^{\prime \prime}\end{array}$ & L5 & 13.0 & 0.2 & 23.4 & 2.7 & 20.0 & 0.8 & S4 \\
\hline GRV022160 & $\begin{array}{l}\mathrm{S}^{\circ} 2^{\circ} 46^{\prime} 54^{\prime \prime} \\
\mathrm{E} 75^{\circ} 18^{\prime} 14^{\prime \prime}\end{array}$ & L5 & 610.1 & 3.2 & 23.7 & 1.8 & 20.4 & 4.6 & S4 \\
\hline GRV022161 & $\begin{array}{l}\mathrm{S}^{\circ} 2^{\circ} 46^{\prime} 54^{\prime \prime} \\
\mathrm{E} 75^{\circ} 18^{\prime} 14^{\prime \prime}\end{array}$ & L5 & 26.5 & 5.8 & 24.0 & 1.8 & 20.6 & 1.0 & S4 \\
\hline GRV022163 & $\begin{array}{l}\mathrm{S}^{\circ} 2^{\circ} 46^{\prime} 54^{\prime \prime} \\
\mathrm{E} 75^{\circ} 18^{\prime} 14^{\prime \prime}\end{array}$ & L5 & 94.3 & 3.8 & 25.7 & 1.8 & 21.4 & 2.3 & S3 \\
\hline GRV022168 & $\begin{array}{l}\mathrm{S}^{\circ} 2^{\circ} 46^{\prime} 54^{\prime \prime} \\
\mathrm{E} 75^{\circ} 18^{\prime} 14^{\prime \prime}\end{array}$ & L5 & 139.7 & 2.1 & 25.2 & 0.7 & 21.2 & 1.4 & S4 \\
\hline GRV022169 & $\begin{array}{l}\mathrm{S} 72^{\circ} 46^{\prime} 54^{\prime \prime} \\
\mathrm{E}^{\circ} 18^{\prime} 10^{\prime \prime}\end{array}$ & L5 & 93.1 & 3.6 & 25.4 & 3.3 & 21.5 & 4.7 & S4 \\
\hline GRV022170 & $\begin{array}{l}\mathrm{S} 72^{\circ} 46^{\prime} 54^{\prime \prime} \\
\mathrm{E}^{\circ} 18^{\prime} 10^{\prime \prime}\end{array}$ & L5 & 80.0 & 3.6 & 25.4 & 2.0 & 22.6 & 2.0 & S5 \\
\hline GRV022177 & $\begin{array}{l}\mathrm{S}^{\circ} 2^{\circ} 46^{\prime} 54^{\prime \prime} \\
\mathrm{E} 75^{\circ} 18^{\prime} 10^{\prime \prime}\end{array}$ & L5 & 34.5 & 3.1 & 23.6 & 1.5 & 20.2 & 1.1 & S4 \\
\hline GRV022185 & $\begin{array}{l}\mathrm{S} 72^{\circ} 46^{\prime} 52^{\prime \prime} \\
\mathrm{E} 75^{\circ} 17^{\prime} 32^{\prime \prime}\end{array}$ & L5 & 13.3 & 3.7 & 23.8 & 1.6 & 20.5 & 1.2 & S2 \\
\hline GRV022186 & $\begin{array}{l}\mathrm{S} 72^{\circ} 46^{\prime} 52^{\prime \prime} \\
\mathrm{E} 75^{\circ} 17^{\prime} 32^{\prime \prime}\end{array}$ & L5 & 12.0 & 4.9 & 23.5 & 1.1 & 20.4 & 0.8 & S2 \\
\hline GRV022190 & $\begin{array}{l}\mathrm{S}^{\circ} 2^{\circ} 46^{\prime} 53^{\prime \prime} \\
\mathrm{E} 75^{\circ} 18^{\prime} 20^{\prime \prime}\end{array}$ & L5 & 42.1 & 6.0 & 23.6 & 0.8 & 20.2 & 1.3 & S2 \\
\hline
\end{tabular}


Table A1. Cont.

\begin{tabular}{|c|c|c|c|c|c|c|c|c|c|}
\hline \multirow{2}{*}{ Meteorites } & \multirow{2}{*}{ Found Location } & \multirow{2}{*}{ Type } & \multirow{2}{*}{ Weight (g) } & \multirow{2}{*}{$\begin{array}{c}\text { Opaque } \\
\text { Mineral (vol\%) }\end{array}$} & \multicolumn{2}{|c|}{ Olivine } & \multicolumn{2}{|c|}{ Low-Ca Pyroxene } & \multirow{2}{*}{ Shock Degrees } \\
\hline & & & & & Fa & PMD & Fs & PMD & \\
\hline GRV022191 & $\begin{array}{l}\mathrm{S}^{\circ} 2^{\circ} 46^{\prime} 53^{\prime \prime} \\
\mathrm{E} 75^{\circ} 18^{\prime} 20^{\prime \prime}\end{array}$ & L5 & 18.8 & 2.6 & 26.0 & 2.6 & 21.7 & 2.6 & S4 \\
\hline GRV022192 & $\begin{array}{l}\mathrm{S} 72^{\circ} 46^{\prime} 53^{\prime \prime} \\
\mathrm{E} 75^{\circ} 18^{\prime} 20^{\prime \prime}\end{array}$ & L5 & 19.0 & 3.2 & 25.4 & 1.9 & 20.7 & 1.3 & S4 \\
\hline GRV022193 & $\begin{array}{l}\mathrm{S} 72^{\circ} 46^{\prime} 53^{\prime \prime} \\
\mathrm{E} 75^{\circ} 18^{\prime} 20^{\prime \prime}\end{array}$ & L5 & 14.8 & 3.9 & 25.4 & 1.7 & 21.9 & 2.6 & S4 \\
\hline GRV022199 & $\begin{array}{l}\mathrm{S} 72^{\circ} 46^{\prime} 51^{\prime \prime} \\
\mathrm{E} 75^{\circ} 18^{\prime} 08^{\prime \prime}\end{array}$ & L5 & 30.1 & 3.6 & 25.6 & 3.2 & 22.1 & 2.6 & S3 \\
\hline GRV022206 & $\begin{array}{l}\mathrm{S} 72^{\circ} 46^{\prime} 51^{\prime \prime} \\
\mathrm{E} 75^{\circ} 18^{\prime} 08^{\prime \prime}\end{array}$ & L5 & 22.5 & 4.7 & 23.7 & 1.6 & 20.8 & 0.8 & S2 \\
\hline GRV022207 & $\begin{array}{l}\mathrm{S} 72^{\circ} 46^{\prime} 51^{\prime \prime} \\
\mathrm{E} 75^{\circ} 18^{\prime} 08^{\prime \prime}\end{array}$ & L5 & 15.8 & 4.7 & 23.4 & 0.8 & 20.0 & 1.5 & S4 \\
\hline GRV022210 & $\begin{array}{l}\mathrm{S} 72^{\circ} 46^{\prime} 42^{\prime \prime} \\
\mathrm{E} 75^{\circ} 19^{\prime} 15^{\prime \prime}\end{array}$ & L5 & 11.8 & 2.0 & 23.3 & 1.0 & 20.4 & 1.1 & S4 \\
\hline GRV022211 & $\begin{array}{l}\mathrm{S} 72^{\circ} 46^{\prime} 42^{\prime \prime} \\
\mathrm{E} 75^{\circ} 19^{\prime} 15^{\prime \prime}\end{array}$ & L5 & 11.1 & 3.7 & 23.5 & 1.0 & 20.2 & 1.2 & S2 \\
\hline GRV022212 & $\begin{array}{l}\mathrm{S} 72^{\circ} 46^{\prime} 42^{\prime \prime} \\
\mathrm{E} 75^{\circ} 19^{\prime} 15^{\prime \prime}\end{array}$ & L5 & 12.1 & 2.2 & 23.9 & 3.5 & 20.4 & 2.7 & S2 \\
\hline GRV022219 & $\begin{array}{l}\mathrm{S} 72^{\circ} 46^{\prime} 42^{\prime \prime} \\
\mathrm{E} 75^{\circ} 19^{\prime} 15^{\prime \prime}\end{array}$ & L5 & 101.0 & 3.6 & 25.6 & 1.8 & 22.0 & 5.9 & S4 \\
\hline GRV022222 & $\begin{array}{l}\mathrm{S} 72^{\circ} 46^{\prime} 42^{\prime \prime} \\
\mathrm{E} 75^{\circ} 19^{\prime} 15^{\prime \prime}\end{array}$ & L5 & 126.0 & 2.2 & 25.5 & 2.0 & 21.6 & 2.1 & S3 \\
\hline GRV022284 & $\begin{array}{l}\mathrm{S} 72^{\circ} 46^{\prime} 47^{\prime \prime} \\
\mathrm{E} 75^{\circ} 17^{\prime} 34^{\prime \prime}\end{array}$ & L5 & 11.9 & 3.2 & 24.0 & 1.2 & 20.7 & 1.3 & S2 \\
\hline GRV022285 & $\begin{array}{l}\mathrm{S} 72^{\circ} 46^{\prime} 47^{\prime \prime} \\
\mathrm{E} 75^{\circ} 17^{\prime} 34^{\prime \prime}\end{array}$ & L5 & 37.1 & 4.1 & 23.8 & 0.8 & 20.4 & 0.9 & S2 \\
\hline GRV022287 & $\begin{array}{l}\mathrm{S} 72^{\circ} 46^{\prime} 47^{\prime \prime} \\
\mathrm{E} 75^{\circ} 17^{\prime} 34^{\prime \prime}\end{array}$ & L5 & 11.1 & 3.1 & 23.4 & 2.9 & 20.2 & 1.1 & S4 \\
\hline GRV022291 & $\begin{array}{l}\mathrm{S} 72^{\circ} 46^{\prime} 46^{\prime \prime} \\
\mathrm{E} 75^{\circ} 17^{\prime} 43^{\prime \prime}\end{array}$ & L5 & 12.2 & 2.8 & 25.1 & 1.5 & 21.8 & 6.4 & S3 \\
\hline GRV022443 & $\begin{array}{l}\mathrm{S} 72^{\circ} 46^{\prime} 23^{\prime \prime} \\
\mathrm{E} 75^{\circ} 20^{\prime} 21^{\prime \prime}\end{array}$ & L5 & 720.9 & 3.2 & 24.9 & 1.5 & 21.9 & 3.6 & S3 \\
\hline GRV022444 & $\begin{array}{l}\mathrm{S} 72^{\circ} 46^{\prime} 23^{\prime \prime} \\
\mathrm{E} 75^{\circ} 20^{\prime} 21^{\prime \prime}\end{array}$ & L5 & 679.2 & 3.3 & 25.4 & 1.4 & 21.4 & 3.5 & S3 \\
\hline GRV020027 & $\begin{array}{l}\mathrm{S} 73^{\circ} 04^{\prime} 09^{\prime \prime} \\
\mathrm{E} 75^{\circ} 16^{\prime} 37^{\prime \prime}\end{array}$ & L6 & 428.8 & 3.8 & 25.8 & 1.6 & 21.9 & 1.8 & S4 \\
\hline GRV020073 & $\begin{array}{l}\mathrm{S} 72^{\circ} 59^{\prime} 56^{\prime \prime} \\
\mathrm{E} 75^{\circ} 12^{\prime} 46^{\prime \prime}\end{array}$ & L6 & 9.0 & 1.8 & 26.4 & 2.8 & 22.4 & 1.2 & S3 \\
\hline GRV020095 & $\begin{array}{l}\mathrm{S} 72^{\circ} 59^{\prime} 43^{\prime \prime} \\
\mathrm{E} 75^{\circ} 12^{\prime} 24^{\prime \prime}\end{array}$ & L6 & 6.1 & 1.4 & 26.5 & 1.3 & 21.9 & 1.6 & S5 \\
\hline GRV020115 & $\begin{array}{l}\mathrm{S} 72^{\circ} 58^{\prime} 43^{\prime \prime} \\
\mathrm{E} 75^{\circ} 15^{\prime} 58^{\prime \prime}\end{array}$ & L6 & 8.3 & 1.1 & 25.8 & 1.3 & 22.0 & 1.9 & S2 \\
\hline GRV020131 & $\begin{array}{l}\mathrm{S} 72^{\circ} 58^{\prime} 37^{\prime \prime} \\
\mathrm{E} 75^{\circ} 15^{\prime} 40^{\prime \prime}\end{array}$ & L6 & 3.8 & 3.9 & 26.0 & 4.1 & 21.8 & 1.1 & S2 \\
\hline GRV020132 & $\begin{array}{l}\mathrm{S} 72^{\circ} 58^{\prime} 38^{\prime \prime} \\
\mathrm{E} 75^{\circ} 15^{\prime} 41^{\prime \prime}\end{array}$ & L6 & 1.9 & 3.4 & 25.8 & 3.3 & 21.7 & 2.2 & S2 \\
\hline GRV020134 & $\begin{array}{l}\mathrm{S} 72^{\circ} 58^{\prime} 41^{\prime \prime} \\
\mathrm{E} 75^{\circ} 15^{\prime} 38^{\prime \prime}\end{array}$ & L6 & 16.4 & 3.8 & 26.4 & 3.0 & 22.2 & 2.3 & S2 \\
\hline GRV020163 & $\begin{array}{l}\mathrm{S} 72^{\circ} 58^{\prime} 35^{\prime \prime} \\
\mathrm{E} 75^{\circ} 15^{\prime} 54^{\prime \prime}\end{array}$ & L6 & 3.4 & 5.4 & 24.7 & 0.8 & 21.0 & 0.8 & S4 \\
\hline GRV020167 & $\begin{array}{l}\mathrm{S} 72^{\circ} 58^{\prime} 41^{\prime \prime} \\
\mathrm{E} 75^{\circ} 15^{\prime} 49^{\prime \prime}\end{array}$ & L6 & 7.5 & 4.1 & 25.9 & 2.3 & 21.7 & 1.1 & S3 \\
\hline GRV021475 & $\begin{array}{l}\mathrm{S} 72^{\circ} 56^{\prime} 35^{\prime \prime} \\
\mathrm{E} 75^{\circ} 16^{\prime} 30^{\prime \prime}\end{array}$ & L6 & 183.7 & 2.5 & 25.2 & 2.5 & 22.1 & 2.5 & S2 \\
\hline GRV021478 & $\begin{array}{l}\mathrm{S} 72^{\circ} 56^{\prime} 06^{\prime \prime} \\
\mathrm{E} 75^{\circ} 19^{\prime} 30^{\prime \prime}\end{array}$ & L6 & 104.5 & 4.4 & 26.4 & 2.2 & 21.9 & 1.0 & S2 \\
\hline GRV021502 & $\begin{array}{l}\mathrm{S} 72^{\circ} 57^{\prime} 06^{\prime \prime} \\
\mathrm{E} 75^{\circ} 16^{\prime} 25^{\prime \prime}\end{array}$ & L6 & 17.4 & 2.2 & 26.0 & 1.4 & 21.9 & 3.0 & S3 \\
\hline GRV021503 & $\begin{array}{l}\mathrm{S} 72^{\circ} 56^{\prime} 54^{\prime \prime} \\
\mathrm{E} 75^{\circ} 15^{\prime} 56^{\prime \prime}\end{array}$ & L6 & 23.6 & 3.3 & 26.1 & 0.8 & 21.8 & 1.0 & S3 \\
\hline GRV021504 & $\begin{array}{l}\mathrm{S} 72^{\circ} 56^{\prime} 55^{\prime \prime} \\
\mathrm{E} 75^{\circ} 15^{\prime} 54^{\prime \prime}\end{array}$ & L6 & 17.8 & 1.5 & 26.1 & 1.8 & 21.8 & 0.7 & S3 \\
\hline GRV021506 & $\begin{array}{l}\mathrm{S} 72^{\circ} 56^{\prime} 42^{\prime \prime} \\
\mathrm{E} 75^{\circ} 15^{\prime} 39^{\prime \prime}\end{array}$ & L6 & 39.1 & 3.5 & 26.1 & 2.0 & 22.5 & 3.9 & S3 \\
\hline GRV021578 & $\begin{array}{l}\mathrm{S} 72^{\circ} 57^{\prime} 46^{\prime \prime} \\
\mathrm{E} 75^{\circ} 14^{\prime} 20^{\prime \prime}\end{array}$ & L6 & 14.4 & 4.0 & 24.3 & 0.8 & 21.0 & 1.0 & S2 \\
\hline GRV021595 & $\begin{array}{l}\mathrm{S} 72^{\circ} 49^{\prime} 28^{\prime \prime} \\
\mathrm{E} 75^{\circ} 17^{\prime} 30^{\prime \prime}\end{array}$ & L6 & 22.5 & 2.7 & 26.3 & 2.5 & 21.8 & 2.2 & S3 \\
\hline GRV021597 & $\begin{array}{l}\mathrm{S} 72^{\circ} 49^{\prime} 29^{\prime \prime} \\
\mathrm{E} 75^{\circ} 17^{\prime} 29^{\prime \prime}\end{array}$ & L6 & 26.8 & 4.3 & 25.8 & 2.1 & 21.7 & 1.2 & S3 \\
\hline GRV021649 & $\begin{array}{l}\mathrm{S}^{\circ} 42^{\circ} 24^{\prime \prime} \\
\mathrm{E} 75^{\circ} 20^{\prime} 00^{\prime \prime}\end{array}$ & L6 & 13.9 & 2.5 & 23.0 & 2.8 & 20.1 & 1.4 & S5 \\
\hline GRV021714 & $\begin{array}{l}\mathrm{S}^{\circ} 47^{\prime} 24^{\prime \prime} \\
\mathrm{E} 75^{\circ} 17^{\prime} 50^{\prime \prime}\end{array}$ & L6 & 136.8 & 2.9 & 23.4 & 1.8 & 20.2 & 1.6 & $\mathrm{~S} 4$ \\
\hline GRV021722 & $\begin{array}{l}\mathrm{S} 72^{\circ} 47^{\prime} 26^{\prime \prime} \\
\mathrm{E} 75^{\circ} 16^{\prime} 58^{\prime \prime}\end{array}$ & L6 & 33.2 & 3.1 & 23.7 & 1.4 & 20.4 & 1.0 & S4 \\
\hline GRV021723 & $\begin{array}{l}\mathrm{S} 72^{\circ} 47^{\prime} 26^{\prime \prime} \\
\mathrm{E} 75^{\circ} 16^{\prime} 37^{\prime \prime}\end{array}$ & L6 & 25.6 & 2.4 & 23.3 & 1.6 & 20.1 & 1.8 & $\mathrm{~S} 4$ \\
\hline GRV021786 & $\begin{array}{l}\mathrm{S} 72^{\circ} 46^{\prime} 31^{\prime \prime} \\
\mathrm{E} 75^{\circ} 20^{\prime} 20^{\prime \prime}\end{array}$ & L6 & 72.5 & 4.0 & 25.1 & 2.3 & 21.5 & 1.6 & S3 \\
\hline
\end{tabular}


Table A1. Cont.

\begin{tabular}{|c|c|c|c|c|c|c|c|c|c|}
\hline \multirow{2}{*}{ Meteorites } & \multirow{2}{*}{ Found Location } & \multirow{2}{*}{ Type } & \multirow{2}{*}{ Weight (g) } & \multirow{2}{*}{$\begin{array}{c}\text { Opaque } \\
\text { Mineral (vol\%) }\end{array}$} & \multicolumn{2}{|c|}{ Olivine } & \multicolumn{2}{|c|}{ Low-Ca Pyroxene } & \multirow{2}{*}{ Shock Degrees } \\
\hline & & & & & Fa & PMD & Fs & PMD & \\
\hline GRV021787 & $\begin{array}{l}\mathrm{S} 72^{\circ} 46^{\prime} 30^{\prime \prime} \\
\mathrm{E} 75^{\circ} 20^{\prime} 30^{\prime \prime}\end{array}$ & L6 & 70.1 & 4.1 & 26.3 & 2.3 & 21.4 & 2.7 & S3 \\
\hline GRV021796 & $\begin{array}{l}\mathrm{S} 72^{\circ} 46^{\prime} 26^{\prime \prime} \\
\mathrm{E} 75^{\circ} 19^{\prime} 27^{\prime \prime}\end{array}$ & L6 & 55.3 & 1.0 & 23.7 & 1.6 & 20.4 & 1.7 & S4 \\
\hline GRV021797 & $\begin{array}{l}\mathrm{S} 72^{\circ} 46^{\prime} 26^{\prime \prime} \\
\mathrm{E}^{\circ} 5^{\circ} 19^{\prime} 28^{\prime \prime}\end{array}$ & L6 & 99.7 & 3.3 & 23.5 & 1.1 & 20.2 & 1.1 & S3 \\
\hline GRV021799 & $\begin{array}{l}\mathrm{S} 72^{\circ} 46^{\prime} 24^{\prime \prime} \\
\mathrm{E} 75^{\circ} 20^{\prime} 01^{\prime \prime}\end{array}$ & L6 & 49.8 & 1.5 & 23.2 & 1.3 & 20.1 & 1.7 & S4 \\
\hline GRV022025 & $\begin{array}{l}\mathrm{S} 72^{\circ} 47^{\prime} 01^{\prime \prime} \\
\mathrm{E}^{\circ} 5^{\circ} 17^{\prime} 47^{\prime \prime}\end{array}$ & L6 & 101.4 & 1.3 & 23.5 & 2.8 & 20.2 & 1.5 & S2 \\
\hline GRV022114 & $\begin{array}{l}\mathrm{S} 72^{\circ} 46^{\prime} 45^{\prime \prime} \\
\mathrm{E}^{\circ} 18^{\prime} 38^{\prime \prime}\end{array}$ & L6 & 171.4 & 1.9 & 23.1 & 1.6 & 19.9 & 1.4 & S4 \\
\hline GRV022129 & $\begin{array}{l}\mathrm{S} 72^{\circ} 46^{\prime} 44^{\prime \prime} \\
\mathrm{E}^{\circ} 18^{\prime} 49^{\prime \prime}\end{array}$ & L6 & 30.2 & 1.8 & 23.6 & 0.9 & 20.4 & 0.7 & S4 \\
\hline GRV022130 & $\begin{array}{l}\mathrm{S} 72^{\circ} 46^{\prime} 44^{\prime \prime} \\
\mathrm{E} 75^{\circ} 18^{\prime} 49^{\prime \prime}\end{array}$ & L6 & 30.5 & 2.0 & 24.5 & 2.9 & 22.0 & 2.8 & S3 \\
\hline GRV022131 & $\begin{array}{l}\mathrm{S} 72^{\circ} 46^{\prime} 44^{\prime \prime} \\
\mathrm{E} 75^{\circ} 18^{\prime} 49^{\prime \prime}\end{array}$ & L6 & 24.8 & 3.3 & 25.5 & 1.8 & 21.8 & 1.8 & S3 \\
\hline GRV022132 & $\begin{array}{l}\text { S72 } 46^{\prime} 44^{\prime \prime} \\
\text { E } 75^{\circ} 18^{\prime} 49^{\prime \prime}\end{array}$ & L6 & 23.9 & 3.2 & 25.4 & 1.9 & 21.3 & 1.7 & S3 \\
\hline GRV022133 & $\begin{array}{l}S 72^{\circ} 46^{\prime} 44^{\prime \prime} \\
\text { E75 } 18^{\prime} 49^{\prime \prime}\end{array}$ & L6 & 21.4 & 3.2 & 25.2 & 0.4 & 21.3 & 1.3 & S3 \\
\hline GRV022134 & $\begin{array}{l}\mathrm{S} 72^{\circ} 46^{\prime} 44^{\prime \prime} \\
\mathrm{E}^{\circ} 18^{\prime} 49^{\prime \prime}\end{array}$ & L6 & 20.0 & 1.1 & 25.7 & 2.5 & 21.5 & 4.0 & S3 \\
\hline GRV022145 & $\begin{array}{l}\mathrm{S} 72^{\circ} 46^{\prime} 44^{\prime \prime} \\
\mathrm{E}^{\circ} 18^{\prime} 49^{\prime \prime}\end{array}$ & L6 & 31.8 & 3.3 & 23.5 & 1.0 & 19.9 & 0.9 & S2 \\
\hline GRV022147 & $\begin{array}{l}\mathrm{S} 72^{\circ} 46^{\prime} 44^{\prime \prime} \\
\mathrm{E}^{\circ} 5^{\circ} 18^{\prime} 49^{\prime \prime}\end{array}$ & L6 & 21.2 & 3.0 & 25.7 & 1.2 & 21.2 & 1.7 & S4 \\
\hline GRV022148 & $\begin{array}{l}\mathrm{S} 72^{\circ} 46^{\prime} 44^{\prime \prime} \\
\mathrm{E}^{\circ} 18^{\circ} 18^{\prime} 49^{\prime \prime}\end{array}$ & L6 & 17.2 & 2.3 & 25.3 & 1.6 & 21.3 & 2.3 & S4 \\
\hline GRV022149 & $\begin{array}{l}S 72^{\circ} 46^{\prime} 44^{\prime \prime} \\
\mathrm{E}^{\circ} 18^{\prime} 19^{\prime \prime} 9^{\prime \prime}\end{array}$ & L6 & 17.2 & 3.6 & 25.9 & 1.2 & 21.3 & 2.2 & S4 \\
\hline GRV022158 & $\begin{array}{l}\mathrm{S} 72^{\circ} 46^{\prime} 44^{\prime \prime} \\
\mathrm{E}^{\circ} 18^{\prime} 49^{\prime \prime}\end{array}$ & L6 & 14.2 & 1.5 & 23.6 & 2.0 & 20.6 & 4.4 & S4 \\
\hline GRV022162 & $\begin{array}{l}\mathrm{S} 72^{\circ} 46^{\prime} 54^{\prime \prime} \\
\mathrm{E}^{\circ} 5^{\circ} 18^{\prime} 14^{\prime \prime}\end{array}$ & L6 & 141.0 & 1.8 & 24.1 & 1.7 & 20.7 & 1.0 & S3 \\
\hline GRV022164 & $\begin{array}{l}\mathrm{S} 72^{\circ} 46^{\prime} 54^{\prime \prime} \\
\mathrm{E}^{\circ} 18^{\prime} 14^{\prime \prime}\end{array}$ & L6 & 14.9 & 2.9 & 25.6 & 1.8 & 22.8 & 3.8 & S4 \\
\hline GRV022178 & $\begin{array}{l}\mathrm{S} 72^{\circ} 46^{\prime} 54^{\prime \prime} \\
\mathrm{E}^{\circ} 15^{\circ} 18^{\prime} 10^{\prime \prime}\end{array}$ & L6 & 23.9 & 3.5 & 23.7 & 1.4 & 20.3 & 1.0 & S4 \\
\hline GRV022194 & $\begin{array}{l}\mathrm{S} 72^{\circ} 46^{\prime} 53^{\prime \prime} \\
\mathrm{E}^{\circ} 18^{\prime} 18^{\prime} 20^{\prime \prime}\end{array}$ & L6 & 15.6 & 2.8 & 25.8 & 3.3 & 21.3 & 3.8 & S5 \\
\hline GRV022220 & $\begin{array}{l}S 72^{\circ} 46^{\prime} 42^{\prime \prime} \\
\mathrm{E} 75^{\circ} 19^{\prime} 15^{\prime \prime}\end{array}$ & L6 & 12.0 & 2.9 & 26.3 & 3.4 & 22.0 & 4.8 & S3 \\
\hline GRV022223 & $\begin{array}{l}\mathrm{S} 72^{\circ} 46^{\prime} 42^{\prime \prime} \\
\mathrm{E}^{\circ} 5^{\circ} 19^{\prime} 15^{\prime \prime}\end{array}$ & L6 & 71.2 & 3.1 & 25.7 & 1.7 & 21.4 & 3.4 & S3 \\
\hline GRV022237 & $\begin{array}{l}\mathrm{S} 72^{\circ} 46^{\prime} 43^{\prime \prime} \\
\mathrm{E} 75^{\circ} 18^{\prime} 55^{\prime \prime}\end{array}$ & L6 & 14.1 & 12.0 & 24.5 & 0.4 & 20.7 & 0.8 & S5 \\
\hline GRV022282 & $\begin{array}{l}\mathrm{S}^{\circ} 2^{\circ} 46^{\prime} 42^{\prime \prime} \\
\mathrm{E}^{\circ} 18^{\prime} 50^{\prime \prime}\end{array}$ & L6 & 43.3 & 3.3 & 24.1 & 1.3 & 20.6 & 1.5 & S2 \\
\hline GRV022288 & $\begin{array}{l}\mathrm{S} 72^{\circ} 46^{\prime} 47^{\prime \prime} \\
\mathrm{E} 75^{\circ} 17^{\prime} 34^{\prime \prime}\end{array}$ & L6 & 33.0 & 2.4 & 25.6 & 3.1 & 21.5 & 3.5 & S3 \\
\hline GRV022289 & $\begin{array}{l}\mathrm{S} 72^{\circ} 46^{\prime} 47^{\prime \prime} \\
\mathrm{E}^{\circ} 17^{\prime} 17^{\prime} 34^{\prime \prime}\end{array}$ & L6 & 38.1 & 2.1 & 24.1 & 4.9 & 22.1 & 3.7 & S4 \\
\hline GRV020021 & $\begin{array}{l}\mathrm{S} 73^{\circ} 05^{\prime} 11^{\prime \prime} \\
\mathrm{E} 75^{\circ} 13^{\prime} 59^{\prime \prime}\end{array}$ & LL4 & 11.3 & 2.2 & 27.5 & 3.4 & 23.7 & 4.2 & S1 \\
\hline GRV020028 & $\begin{array}{l}\mathrm{S} 73^{\circ} 04^{\prime} 23^{\prime \prime} \\
\mathrm{E} 75^{\circ} 16^{\prime} 08^{\prime \prime}\end{array}$ & LL4 & 10.1 & 3.3 & 28.2 & 1.0 & 23.1 & 2.5 & S3 \\
\hline GRV020037 & $\begin{array}{l}\mathrm{S} 73^{\circ} 06^{\prime} 20^{\prime \prime} \\
\mathrm{E} 75^{\circ} 10^{\prime} 14^{\prime \prime}\end{array}$ & LL4 & 1.6 & 2.8 & 28.4 & 1.2 & 23.8 & 4.6 & S1 \\
\hline GRV020041 & $\begin{array}{l}\mathrm{S}_{7}^{\circ} 06^{\prime} 19^{\prime \prime} \\
\mathrm{E}^{\circ} 09^{\prime} 08^{\prime \prime}\end{array}$ & LL4 & 1.4 & 4.1 & 28.1 & 0.9 & 23.7 & 4.0 & S1 \\
\hline GRV020019 & $\begin{array}{l}S 73^{\circ} 05^{\prime} 02^{\prime \prime} \\
\mathrm{E} 75^{\circ} 12^{\prime} 59^{\prime \prime}\end{array}$ & LL5 & 10.1 & 0.6 & 31.6 & 2.3 & 27.2 & 2.6 & S2 \\
\hline
\end{tabular}

\section{References}

1. Liu, X.; Zhao, Y.; Liu, X.; Yu, L. Geological characteristics of Grove Mountains, East Antarctica: New proof of final suture of Gondwana. Chin. Sci. D 2002, 32, 457-468.

2. Kimura, M.; Lin, Y.; Ikeda, Y.; Goresy, A.E.; Yanai, K.; Kojima, H. Mineralogy of Antarctic aubrites, Yamato-793592 and Allan Hills-78113: Comparison with non-Antarctic aubrites and E-chondrites. Antarct. Meteor. Res. 1993, 6, 186-203. 
3. Nobuyoshi, T.; Haramura, H.; Ikeda, Y.; Kimura, M.; Kojima, H.; Imae, N.; Lee, M.S. Comparative study of the major element chemical compositions of Antarctic chondrites to those of non-Antarcitc falls with reference to terrestrial weathering. Antarct. Meteor. Res. 1997, 10, 165-180.

4. Takeda, H.; Mori, H.; Saito, J.; Miyamoto, M. Mineral-chemical comparisons of MAC88105 with Yamato lunar meteorites. Geochim. Cosmochim. Acta 1991, 55, 3009-3017. [CrossRef]

5. Welten, K.C.; Nishiizumi, K.; Caffee, M.W.; Hillegonds, D.J.; Johnson, J.A.; Jull, A.J.T.; Wieler, R.; Folco, L. Terrestrial ages, pairing, and concentration mechanism of Antarctic chondrites from Frontier Mountain, Northern Victoria Land. Meteorit. Planet. Sci. 2006, 41, 1081-1094. [CrossRef]

6. Chen, M.; El Goresy, A.; Gillet, P. Ringwoodite lamellae in olivine: Clues to olivine-ringwoodite phase transition mechanisms in shocked meteorites and subducting slabs. Proc. Natl. Acad. Sci. USA 2004, 101, 15033-15037. [CrossRef] [PubMed]

7. Tomioka, N.; Miyahara, M. High-pressure minerals in shocked meteorites. Meteorit. Planet. Sci. 2017, 52, $2017-2039$. [CrossRef]

8. Miyahara, M.; El Goresy, A.; Ohtani, E.; Nagase, T.; Nishijima, M.; Vashaei, Z.; Ferroir, T.; Gillet, P.; Dubrovinsky, L.; Simionovici, A. Evidence for fractional crystallization of wadsleyite and ringwoodite from olivine melts in chondrules entrained in shock-melt veins. Proc. Natl. Acad. Sci. USA 2008, 105, 8542-8547. [CrossRef] [PubMed]

9. Yin, F.; Liao, Z.; Hursthouse, A.; Dai, D. Shock-Induced Olivine-Ringwoodite Transformation in the Shock Vein of Chondrite GRV053584. Minerals 2008. [CrossRef]

10. Feng, L.; Lin, Y.; Hu, S.; Xu, L.; Miao, B. Estimating compositions of natural ringwoodite in the heavily shocked Grove Mountains 052049 meteorite from Raman spectra. Am. Mineral. 2011, 96, 1480-1489. [CrossRef]

11. Feng, L.; Lin, Y.; Hu, S.; Liu, T. Shock metamorphism of ordinary chondrites from Grove Mountains, Antarctica. Chin. J. Pol. Sci. 2009, 20, 187-199.

12. Lin, Y.; Wang, D.; Ouyang, Z. Progress in study of Chinese Antarctica Meteorites. Chin. J. Pol. Sci. 2009, 20, 81-96.

13. Stöffler, D.; Keil, K.; Scott, E.R.D. Shock metamorphism of ordinary chondrites. Geochim. Cosmochim. Acta 1991, 55, 3845-3867. [CrossRef]

14. Miao, B. The status of Antarctic meteorite research in China and the prospect on its development. Bull. Mineral. Petrol. Geochem. 2015, 34, 1081-1089. (In Chinese)

15. Van Schmus, W.R.; Wood, J.A. A chemical-petrologic classification for the chondritic meteorites. Geochim. Cosmochim. Acta 1967, 31, 747-765. [CrossRef]

16. Miao, B.; Lin, Y.; Ouyang, Z.; Zhou, X. Type distribution pattern and pairing of ordinary chondrites from Grove Mountains, Antarctica. Chin. Sci. Bull. 2003, 48, 908-913.

17. Miao, B.; Wang, D. Classification of Grove Mountains meteorites and its significance. Chin. J. Pol. Sci. 2009, 20, 97-109.

18. Lu, R.; Miao, B.; Wang, G.; Dai, D.; Lin, Y.; Ouyang, Z.; Li, C. Classification of 24 New Ordinary Chondrites from Grove Mountains, Antarctica. Acta Geol. Sin. 2004, 78, 1052-1059.

19. Fritz, J.; Greshake, A.; Fernandes, V.A. Revising the shock classification of meteorites. Meteorit. Planet. Sci. 2017, 52, 1216-1232. [CrossRef]

20. Rubie, D.C.; Ross, C.R. Kinetics of the olivine-spinel transformation in subducting lithosphere: Experimental constraints and implications for deep slab processes. Phys. Earth Planet. Int. 1994, 86, 223-243. [CrossRef]

21. Pittarello, L.; Ji, G.; Yamaguchi, A.; Schryvers, D.; Debaille, V.; Claeys, P. From olivine to ringwoodite: A TEM study of a complex process. Meteorit. Planet. Sci. 2015, 50, 944-957. [CrossRef]

22. Chen, M.; Li, H.; El Goresy, A.; Liu, J.; Xie, X. Fracture-related intracrystalline transformation of olivine to ringwoodite in the shocked Sixiangkou meteorite. Meteorit. Planet. Sci. 2006, 41, 731-737. [CrossRef]

23. Stöffler, D.; Keil, K.; Scott, E.R.D. Shock classification of ordinary chondrites: New data and interpretations. Meteoritics 1992, 27, 292-293.

24. Sharp, T.G.; Xie, Z.; DeCarli, P.S.; Hu, J. A large shock vein in L chondrite Roosevelt County 106: Evidence for a long-duration shock pulse on the L chondrite parent body. Meteorit. Planet. Sci. 2015, 50, 1941-1953. [CrossRef] 
25. Walton, E.L. Shock metamorphism of Elephant Moraine A79001: Implications for olivine-ringwoodite transformation and the complex thermal history of heavily shocked Martian meteorites. Geochim. Cosmochim. Acta 2013, 107, 299-315. [CrossRef]

26. Greshake, A.; Fritz, J.; Böttger, U.; Goran, D. Shear-induced ringwoodite formation in the Martian shergottite Dar al Gani 670. Earth Planet. Sci. Lett. 2013, 375, 383-394. [CrossRef]

27. Ma, C.; Tschauner, O.; Beckett, J.R.; Liu, Y.; Rossman, G.R.; Sinogeikin, S.V.; Smith, J.S.; Taylor, L.A. Ahrensite, $\gamma-\mathrm{Fe}_{2} \mathrm{SiO}_{4}$, a new shock-metamorphic mineral from the Tissint meteorite: Implications for the Tissint shock event on Mars. Geochim. Cosmochim. Acta 2016, 184, 240-256. [CrossRef]

28. Barrat, J.A.; Chaussidon, M.; Bohn, M.; Gillet, P.; Göpel, C.; Lesourd, M. Lithium behavior during cooling of a dry basalt: An ion-microprobe study of the lunar meteorite Northwest Africa 479 (NWA 479). Geochim. Cosmochim. Acta 2005, 69, 5597-5609. [CrossRef]

29. Zhang, A.C.; Hsu, W.B.; Floss, C.; Li, X.H.; Li, Q.L.; Liu, Y.; Taylor, L.A. Petrogenesis of lunar meteorite Northwest Africa 2977: Constrains from in situ microprobe results. Meteorit. Planet. Sci. 2010, 45, 1929-1947. [CrossRef]

30. Ohtani, E.; Ozawa, S.; Miyahara, M.; Ito, Y.; Mikouchi, T.; Kimura, M.; Arai, T.; Sato, K.; Hiraga, K. Coesite and stishovite in a shocked lunar meteorite, Asuka-881757, and impact events in lunar surface. Proc. Natl. Acad. Sci. USA 2011, 108, 463-466. [CrossRef] [PubMed]

31. Miyahara, M.; Kaneko, S.; Ohtani, E.; Sakai, T.; Nagase, T.; Kayama, M.; Nishido, H.; Hirao, N. Discovery of seifertite in a shocked lunar meteorite. Nat. Commun. 2013, 4. [CrossRef] [PubMed]

32. Kaneko, S.; Miyahara, M.; Ohtani, E.; Arai, T.; Hirao, N.; Sato, K. Discovery of stishovite in Apollo 15299 sample. Am. Mineral. 2015, 100, 1308-1311. [CrossRef]

(C) 2018 by the authors. Licensee MDPI, Basel, Switzerland. This article is an open access article distributed under the terms and conditions of the Creative Commons Attribution (CC BY) license (http:/ / creativecommons.org/licenses/by/4.0/). 